\title{
Low-Temperature Catalytic Gasification of Wet Industrial Wastes
}

FY 1989-1990 Interim Report
D. C. Elliott
G. G. Neuenschwander
E. G. Baker
L. J. Sealock, Jr.
R. S. Butner

April 1991

Prepared for the U.S. Department of Energy under Contract DE-AC06-76RLO 1830

Pacific Northwest Laboratory Operated for the U.S. Department of Energy by Battelle Memorial Institute 


\title{
DISCLAIMER
}

This report was prepared as an account of work sponsored by an agency of the United States Government. Neither the United States Government nor any agency thereof, nor Battelle Memorial Institute, nor any of their employees, makes any warranty, expressed or implied, or assumes any legal liability or responsibility for the accuracy, completeness, or usefulness of any information, apparatus, product, or process disclosed, or represents that its use would not infringe privatefy owned rights. Reference herein to any specific commercial product, process, or service by trade name, trademark, manufacturer, or otherwise does not necessarily constitute or imply its endorsement, recommendation, or favoring by the United States Government or any agency thereof, or Battelle Memorial institute. The views and opinions of authors expressed herein do not necessarily state or reflect those of the United States Government or any agency thereof.

\author{
PACIFIC NORTHWEST LABORATORY \\ operated by \\ BATTELLE MEMORIAL INSTITUTE \\ for the \\ UNITED STATES DEPARTMENT OF ENERGY \\ under Contract DE-ACO6.76RLO 1830
}

Printed in the United States of America

Available to DOE and DOE contractors from the

Office of Scientific and Technical Information, P.O. Box 62, Oak Ridge, TN 37831; prices available from (615) 576-8401. FTS 626-8401.

Available to the public from the National Jechnical Information Service, U.S. Department of Commerce, 5285 Port Royal Rd., Springfield, VA 22161. 
PNL -7671

UC-311

LOW-TEMPERATURE CATALYTIC GASIFICATION

OF WET INDUSTRIAL WASTES

FY 1989-1990 INTERIM REPORT

D. C. Elliott

G. G. Neuenschwander

E. G. Baker

L. J. Sealock, Jr.

R. S. Butner

April 1991

Prepared for

the U.S. Department of Energy

under Contract DE-AC06-76RLO 1830

Pacific Northwest Laboratory

Richland, Washington 99352 


\section{SUMMARY}

Bench-scale reactor tests are in progress at Pacific Northwest Laboratory to develop a low-temperature, catalytic gasification system. The system, 1 icensed under the trade name Thermochemical Environmental Energy System $\left(\right.$ TEES $\left.^{(}\right),{ }^{(a)}$ is designed for treating a wide variety of feedstocks ranging from dilute organics in water to waste sludges from food processing. This report describes a test program which used a continuous-feed tubular reactor. This test program is an intermediate stage in the process development. The reactor is a laboratory-scale version of the commercial concept as currently envisioned by the process developers.

Results showed that feedstocks, such as solutions of $2 \%$ para-cresol or $5 \%$ and $10 \%$ ractose in water or cheese whey, could be processed to $>99 \%$ reduction of chemical oxygen demand (COD) at a rate of up to $2 \mathrm{~L} / \mathrm{hr}$. The estimated residence time was $7 \mathrm{~min}$ at $360^{\circ} \mathrm{C}$ and $3000 \mathrm{psig}$, not including 1 to $2 \mathrm{~min}$ required in the preheating zone of the reactor. The liquid hourly space velocity varied from 1.8 to $4.6 \mathrm{~L}$ feedstock/L catalyst/hr depending on the feedstock. The product gas composition also varied with feedstock while consistent results could be obtained with any given feedstock. The product fuel gas contained $45 \%$ to $70 \%$ methane, $25 \%$ to $50 \%$ carbon dioxide, and $<5 \%$ hydrogen with as much as $2 \%$ ethane but less than $0.1 \%$ ethylene or carbon monoxide, and small amounts of higher hydrocarbons. Representative results from cheese whey show production of $1350 \mathrm{SCF} /$ wet ton $(22,500 \mathrm{SCF} / \mathrm{dry}$ ton) of medium-Btu gas containing $590 \mathrm{Btu} / \mathrm{SCF}$. Similar results for $1.8 \%$ para-creso 1 in water are $820 \mathrm{SCF} /$ wet ton $(45,800 \mathrm{SCF} /$ dry ton $)$ of medium-Btu containing $630 \mathrm{Btu} / \mathrm{SCF}$. The byproduct water stream carried residual organics from 40 to $500 \mathrm{mg} / \mathrm{L} \mathrm{COD}$, depending on the feedstock. The catalysts evaluated in the project consisted of nickel metal on various inert supports. These commercial catalysts were not specifically designed for our process, but were tested to determine their applicability.

(a) TEES ${ }^{\odot}$ is a registered servicemark of Onsite*Ofsite, Inc., Pasadena, California. 
An energy benefit and economic analysis was also completed on the process. Four conceptual commercial installations of the TEES process were evaluated for three food processing applications and one organic chemical manufacturing application. Net energy production (medium-Btu gas) was achieved in all four cases. The organic chemical application was found to be economically attractive in the present situation. Based on sensitivity studies included in the analysis, the three food processing cases will likely become attractive in the near future as waste disposal regulations tighten and disposal costs increase.

TEES potentialiy has a broad application to treatment of wet industrial wastes. Potential feedstocks vary from dilute organic chemical bearing wastewaters containing 100 to $10,000 \mathrm{ppm}$ of COD contaminant to food processing wastes having $10 \%$ to $20 \%$ dry solids. The process has the advantage of being able to efficiently treat waste streams that are toxic or too concentrated for biological treatment or are too dilute for incineration. The process can potentially reduce waste treatment costs and minimize process emissions while producing a useful fuel gas product. 


\section{ACKNOWLEDGMENTS}

Funding for this research project, Low-Temperature Catalytic Gasification of Wet Industrial Wastes, was provided by the Office of Industrial Programs (now the Office of Industrial Technology, Waste Material Management Division) of the U.S. Department of Energy (DOE), Conservation and Renewable Energy. We acknowledge the guidance and support of Stuart Natof, the program manager for this project at DOE-Headquarters.

The process design, costing, and economic analys is found in this report were performed under subcontract to Pacific Northwest Laboratory by Onsite ${ }^{0}$ fsite, Inc., under the supervision of Norman Banns, president. The project manager at Onsite ${ }^{\circ} 0$ ssite was Ted Scheer.

The catalysts were provided for our studies by the catalyst manufacturers as 1 isted in this report under MATERIALS TESTED. Particularly, we acknowledge the support of Jens Houken of Haldor Topsoe; Witliam McKinney of United Catalyst; and Harry Ford, George Shea, and Irvin Feins of Engelhard in providing catalyst samples and useful discussions of results. 


\section{CONTENTS}

SUMMARY

ACKNOWLEDGMENTS . . . . . . . . . . . . . . . . . . . . . V v

INTRODUCTION . . . . . . . . . . . . . . . . . . . . . . . . 1

CONCLUSIONS AND RECOMMENDATIONS . . . . . . . . . . . . . . . . 3

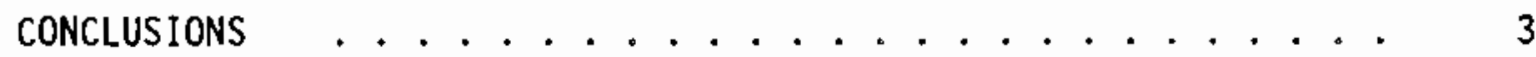

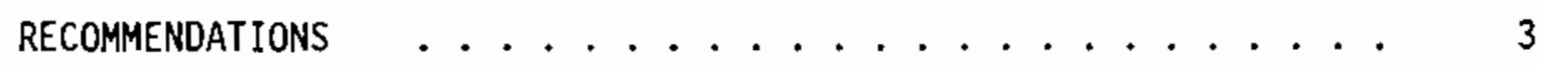

CONTINUOUS REACTOR SYSTEM . . . . . . . . . . . . . . . . 5

MATERIALS TESTED . . . . . . . . . . . . . . . . . . 5

Feedstocks ..................... 5

Catalysts ..................... 5

CRS DESIGN COMPONENTS ......................... 7

Feed Pretreatment and Preparation . . . . . . . . . 7

Pumping . . . . . . . . . . . . . . . . . . 7

Reactor .................... . . . 9

Reaction Products Separation .............. 9

Instrumentation and Control ............. 10

Safety Requirements ................. . 11

PROCEDURES . . . . . . . . . . . . . . . . . . . . . . 13

CRS OPERATION . . . . . . . . . . . . . . . . . . . . . . 13

ANALYTICAL PROCEDURES . . . . . . . . . . . . . . . . . . 14

Elemental Analysis .................... 14

Aqueous COD Analysis .................. 14

Gas Product Analysis .................. 14

EXPERIMENTAL RESULTS . . . . . . . . . . . . . . . . . . 17 
PROCESSING TEST RESULTS . . . . . . . . . . . 17

Lactose Tests .................... 18

Cheese whey Tests ............... 20

Phenol Tests ..................... 22

Spent Grain Tests ................ . . . . 24

Para-Cresot, Hexone, and Sucrose Tests ........ 24

BATCH EXPERIMENTS ........................ 27

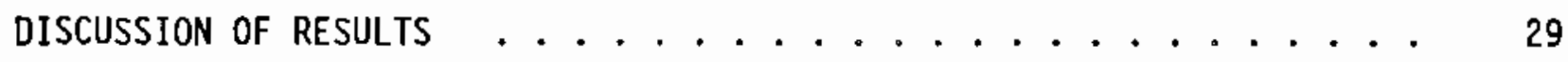

CATALYST EFFECTS . . . . . . . . . . . . . . . 29

PROCESS KINETICS ...................... 30

Physical Characterization of the System ....... 30

Kinetics Calculations ................. 32

CORROSION ABATEMENT REVIEW . . . . . . . . . . . . 37

CHEMICAL CORROSION ........................... 37

HYDROGEN EMBRITTLEMENT . . . . . . . . . . . . . . 38

STRESS CORROSION CRACKING ........................ 38

CHLORIDE CORROSION ................................ 39

SUGGESTIONS FOR CORROSION ABATEMENT BASED ON LITERATURE

REVIEW ......................... 40

EXPERIMENTAL RESULTS WITH CORROSION-TESTING COUPONS ...... 41

TEES ENERGY BENEFIT AND ECONOMIC ANALYSIS . . . . . . . . . . . 43

ECONOMIC ANALYSIS CONCLUSIONS ................. 45

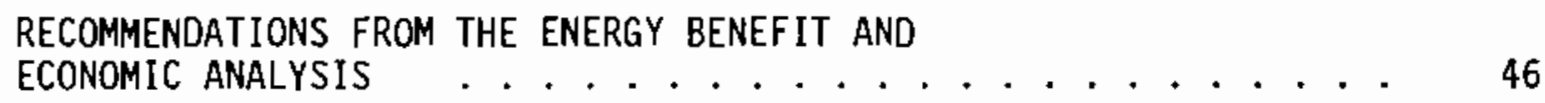

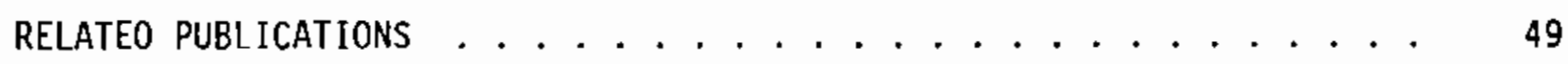

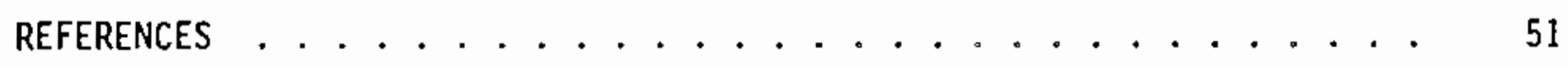




\section{FIGURES}

1 Continuous Reactor System . . . . . . . . . . . . 8

2 Pseudotracer Test Results ............... 33

\section{$\underline{\text { IABLES }}$}

1 Catalyst Compositions and Properties .......... 6

2 Test Results of Nickel-Catalyzed Gasification of Lactose . . . 19

3 Test Results of Nickel-Catalyzed Gasification of Cheese whey . . 21

4 Test Results of Nickel-Catalyzed Gasification of Phenol . . . . 23

5 Test Results of Nickel-Catalyzed Gasification of Spent Grain . . 25

6 Test Results of Nicke1-Catalyzed Gasification of Para-Cresol, Hexone, and Sucrose ............... 26

7 Results from Batch Reactor Experiments with Different Catalysts ...................... 28

8 Calculated Liquid Hourly Space Velocities and Residence Times ................... . . 32

9 Kinetics Calculations for Tubular Reactor Tests . . . . . . 34 
- 


\section{INTRODUCTION}

A catalytic gasification system that operates in a pressurized water environment has been under deve]opment at Pacific Northwest Laboratory (PNL) $^{(a)}$ for over 10 years. Initial experiments, performed for the Gas Research Institute, were aimed at developing kinetics information for steam gasification of biomass in the presence of catalysts [SeaTock et al. 1981]. In that work, the combined use of alkali and metal catalysts was first reported for gasification of biomass and its components at low temperatures $\left(350^{\circ} \mathrm{C}\right.$ to $\left.450^{\circ} \mathrm{C}\right)$ [E17iott and Sealock 1985].

From the fundamental research evolved the concept of a pressurized, catalytic gasification system for converting wet biomass feedstocks to fue 1 gas [Elliott, Butner, and Sealock 1988]. Extensive batch reactor testing [Sealock et al. 1988] and limited continuous reactor system (CRS) testing [Elliott et a]. 1989] were undertaken in the development of this system under sponsorship of the U.S. Department of Energy, Conservation and Renewable Energy. A wide range of biomass feedstocks were tested, and the importance of the nickel metal catalyst was identified. Specific use of this process for treating food processing wastes has also been reported [Baker et al. 1989a]. Furthermore, the concept application has been expanded to encompass cleanup of hazardous wastewater streams, and both batch reactor test results [Baker and Sealock 1988] and continuous reactor test results [Baker et a]. 1989b] have been reported.

The process has now been 1 icensed as the Thermochemical Environmentat Energy System (TEES ${ }^{\oplus}$ ) to Onsite*0fsite, Inc., of Pasadena, California, a turnkey design engineering and construction management firm. TEES was recognized in 1989 with an R\&D 100 Award from Research \& Development Magazine as one of the top 100 new technical developments to reach the marketplace.

This report provides the results of CRS studies conducted with a fixedbed, continuous-feed, tubular reactor. Earlier CRS tests [E11iott et al.

(a) Operated for the U.S. Department of Energy by Battelle Memorial Institute under Contract DE-AC06-76RL0 1830. 
1989] used a Carberry spinning basket reactor, which is physically equivalent to a continuous stirred-tank reactor (CSTR). The kinetic parameters obtained from the CSTR were used to design the tubular reactor, which is more suitable for providing high conversions and for simulating scaleup units. The report also contains a corrosion abatement review and an energy benefit and economic analysis for the TEES process.

The work described in this report was performed during the period from September 1, 1989 to September 30, 1990. The process development research will continue into FY 1991. Evaluation of the effect of scaleup on the process is planned for FY 1991 in a half ton (wet) per day unit. Procurement of components for the unit was begun early in FY 1991 based on contract negotiations initiated in August 1990.

The nickel catalysts tested in the CRS are commercially available, and were not designed specifically for our process. Therefore, the results do not constitute any judgment on the ability of the catalysts to perform at conditions for which they were designed. 


\section{CONCLUSIONS AND RECOMMENDATIONS}

After 1 year of operation of the CRS in the tubuTar reactor configuration we have made significant progress in the development of the TEES process. Based on the results, the following conclusions and recommendations were formulated.

\section{CONCLUSIONS}

- The tubular reactor provides useful engineering information for scaleup purposes. Designs of tubular reactors based on the Carberry reactor kinetics are valid.

- A range of feedstocks can be converted in excess of $99 \%$ in a tubular reactor system. High methane yields are achieved.

- Catalysts have been evaluated, and a useful composition has been identified. Stability over $48 \mathrm{hr}$ of operation was verified. Shutdown and restart of the catalyst bed was demonstrated.

- Conceptual economics have verified the viability of the TEES process in one present-term organic chemical manufacturing case and suggested economic viability for three other food processing cases with assumed future waste disposal cost increases. Net fuel gas yields totaling 10.4 trillion Btu annually are possible using the food processing wastes in the three cases studied. Many other potential applications exist.

\section{RECOMMENDATIONS}

- Continue bench-scale testing of the TEES process to test other feedstocks as a means of developing industrial interest and verifying catalyst compatibility.

- Pursue industrial participation in the process development effort.

- Perform long-term tests to evaluate catalyst stability.

- Scale up the TEES process to include product/feedstock heat exchange and in order to evaluate the effect of scaleup on the process.

- Continue catalyst development efforts on the bench-scale to identify more active and stable catalysts for the high-pressure liquid and steam phase reaction environment. 


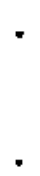




\section{CONTINUOUS REACTOR SYSTEM}

The CRS design components are described here, along with the materials tested in the system.

\section{MATERIALS TESTED}

The feedstocks and catalysts used in the experiments are identified below.

\section{Feedstocks}

Two types of feedstocks were tested: 1) aqueous solution of chemicals to simulate waste chemicals or to act as models of food processing wastes and 2) actual food processing wastes. Specifically, para-cresol and hexone (methylisobutylketone) were used to simulate chemical wastes; and sucrose and lactose were tested as models for plant carbohydrates and cheese whey, respectively. The use of the models allowed tests to be performed on the organic structure without interference of potential catalyst poisons such as alkali, sulfur, or chlorine. Several forms of cheese whey were tested: raw cheese whey, cheese whey permeate (filtered for protein removal), and delactosed cheese whey (processed to concentrate a lactose-depleted whey). Spent grain from a beer brewery was also tested.

\section{Catalysts}

Several types of nickel catalysts were used in the experiments. The primary component was reduced nickel metal on an inert support. The catalysts tested in this project cover a range of nickel concentrations and support materials. Details of the compositions and properties are given in Table 1 .

In addition to the nickel catalyst, sodium carbonate was added in one experiment to determine the effect of alkali on the catalyzed reactions. The sodium carbonate used in that experiment was reagent-grade anhydrous powder packaged by Baker (Lot \#143082). 
IABLE 1. Catalyst Compositions and Properties

\begin{tabular}{|c|c|c|c|c|c|c|c|c|c|c|c|c|}
\hline $\begin{array}{c}\text { Catalyst } \\
\text { Ident if ier }\end{array}$ & Hanufacturer & $\begin{array}{r}\mathrm{Ni} \\
-x \\
\end{array}$ & $\begin{array}{l}\mathrm{C} \\
z \\
\end{array}$ & $\begin{array}{l}11 \\
.5 \\
\end{array}$ & $\begin{array}{c}\text { Support } \\
\text { Type } \\
\end{array}$ & $\begin{array}{l}\mathrm{Ni} \times \mathrm{TL}^{(\mathrm{a})} \\
\text { Size. } \Lambda \\
\end{array}$ & $\begin{array}{l}S A^{(b)} \\
m^{2} / q \\
\end{array}$ & $\begin{array}{l}\mathrm{PV}(\mathrm{c}) \\
\mathrm{cc} / \mathrm{q} \\
\end{array}$ & $\begin{array}{l}\mathrm{ABD}{ }^{(d)} \\
\mathrm{g} / \mathrm{mL}\end{array}$ & $\begin{array}{l}\text { APV }(e) \\
-x \\
\end{array}$ & $\begin{array}{l}\text { Particle } \\
\text { Size Used } \\
\end{array}$ & $\begin{array}{r}N 1 \\
\text { State } \\
\end{array}$ \\
\hline G-658RS & United & 27 & 4.9 & 0.4 & CaAluminate & 166 & $35-65$ & 8.25 & 1.84 & 65 & $1 / 4 T^{(f)}$ & reduced \\
\hline$C 46-7-83$ & United & 52 & 0.0 & 0.5 & $\mathrm{SiO}_{2} / \mathrm{Al}_{2} \mathrm{O}_{3}$ & $<160$ & $25 \theta-35 \theta$ & 0.4 & 3.84 & 78 & $1 / 8 \mathrm{E}^{(9)}$ & reduced \\
\hline G-49BRS & United & 58 & 6.7 & 9.5 & Kiese lguhr & $<10 \theta$ & $75-175$ & 0.3 & 1.41 & 62 & $3 / 16 \times 1 / 8 \mathrm{~T}$ & reduced \\
\hline $\mathrm{Ni}-3210$ & Enge thard & 35 & 4.1 & 1.1 & propríetary & $?$ & 168 & 0.35 & 0.98 & $?$ & $1 / 8 \mathrm{~T}$ & reduced \\
\hline $\mathrm{Ni}-\$ 7553$ & Enge lhard & 48 & 0.35 & a. 56 & $y$-a lumina & 80 & 145 & 0.53 & 0.76 & 89 & $1 / 8 \mathrm{E}$ & reduced \\
\hline$R-67$ & Haldor Topsoe & $12-14$ & 0.15 & 0.26 & $\mathrm{MgAl}_{2} \mathrm{O}_{4}$ & $?$ & $30-35$ & $?$ & 1.06 & $?$ & $3 / 16 Y$ & oxide \\
\hline C11-9-64 & United & 20 & 8.0 & 0.0 & $\alpha-a$ lumina & 136 & $3-16$ & $0.1-0.2$ & 1.36 & $?$ & ${ }_{168}^{5 / 8 x} \mid(h)^{\times 5 /}$ & $\begin{array}{l}\text { reduced } \\
\text { in situ }\end{array}$ \\
\hline RXNR & Ha ldor Topsoe & 25 & 0.89 & 0.29 & $\mathrm{MgO} / \mathrm{Al}_{2} \mathrm{O}_{3}$ & $?$ & 30 & $?$ & $?$ & $?$ & $3 / 16 \mathrm{~T}$ & reduced \\
\hline C158-1-01RS & United & 61.5 & 3.7 & 0.24 & $\mathrm{SiO}_{2} / \mathrm{Al}_{2} \mathrm{O}_{3}$ & $?$ & $?$ & $04 .-6.5$ & $?$ & $?$ & $3 / 16 \times 3 / 32 T$ & reduced \\
\hline PK-5 & Haldor Topsoe & 27 & 8.8 & 0.7 & n-a lumina & $?$ & 250 & 8.85 & $?$ & $?$ & $1 / 4 R^{(h)}$ & $\begin{array}{l}\text { reduced } \\
\text { in situ }\end{array}$ \\
\hline
\end{tabular}

(a) Average crystallite size from $x$-ray diffraction using Scherrer equation.

(b) BET surface area.

(c) Pore volume.

(d) Apparent bull density.

(e) Apparent pore volume by liquid water displacement at ambient conditions.

(f) Tablet, diameter and height in inches.

(g) Extrudate, diameter in inches.

(h) Ring. $00(X$ Ht $X$ ID $)$ in inches. 


\section{CRS DESIGN COMPONENTS}

The CRS was composed of five major functional subsystems: feed pretreatment and preparation; pumping; reactor; reaction products separation; and instrumentation and control. The system was based on a throughput of 0.5 to $10 \mathrm{lb}$ of slurry/solution per hour, and was typically operated over a range of 1 to $2 \mathrm{~L} / \mathrm{hr}$. The system is shown schematically in Figure 1.

\section{Feed Pretreatment and Preparation}

The feedstock pretreatment and preparation method was designed to ensure a relatively homogeneous feed for the reactor. For spent grain slurries, a Union Process 2.5-gal agitated media attrition mill (Model 1-S) with 0.25-in. diameter $X 0.5$-in. diagonally cut stainless steel (SS) media was used to wetmill the material to -18 mesh. The slurries were prepared in 1 -gal batches and required blending at approximately $600 \mathrm{rpm}$ for 15 to $30 \mathrm{~min}$. Dejonized water was added to achieve the desired consistency. Slurries containing between 1 and 5 wt\% solids were processed.

For some feedstocks (1actose or other chemicals), feed preparation involved simply stirring the feedstock or blending the feedstock with deionized water. Cheese whey was fed as received or was further diluted with deionized water.

\section{Pumping}

The pumping subsystem was designed to operate at feed pressures up to $6000 \mathrm{psig}$ and flow rates between 0.2 and $4.0 \mathrm{~L} / \mathrm{hr}$. A Milton Roy Milroyal A reciprocating, packed-plunger, positive-displacement pump was used to meet the design objectives. The pump was equipped with check valves containing 3/8-in.-diameter balls. System piping included 0.5-in. (0.065-wa11) 304 SS tubing on the outlet of the pump. Pump inlet piping was 0.5-in. (0.035-wa11) 304 SS tubing. All valves and valve trim (except the pressure-control valve) were also made of stainiess steel.

Feeding rates were not measured directly because a flowmeter that could work at low flow rates and high pressures could not be obtained. Instead, the flow rate was calculated by measuring the rate of level change on a calibrated glass feed tank equipped with a millimeter scale along the side. 
1. MItron-Roy Pump

$2 t^{*} \mathrm{ID} \times 72^{*}$ Tubular Reactor

3. $6 \mathrm{KW} 3$-zone Furnuce

4. SD Hicron Finer

5. Primary Condenser

6. Badget Pressura Letdown Valve

7. Condensation Pot

8. Liquid Collection Tank
9. Llquid Sample Loop

10. Secondary Condenger

11. Finor

12. Gas Flow Meter

13. Flast Trap for Condensed Liquid

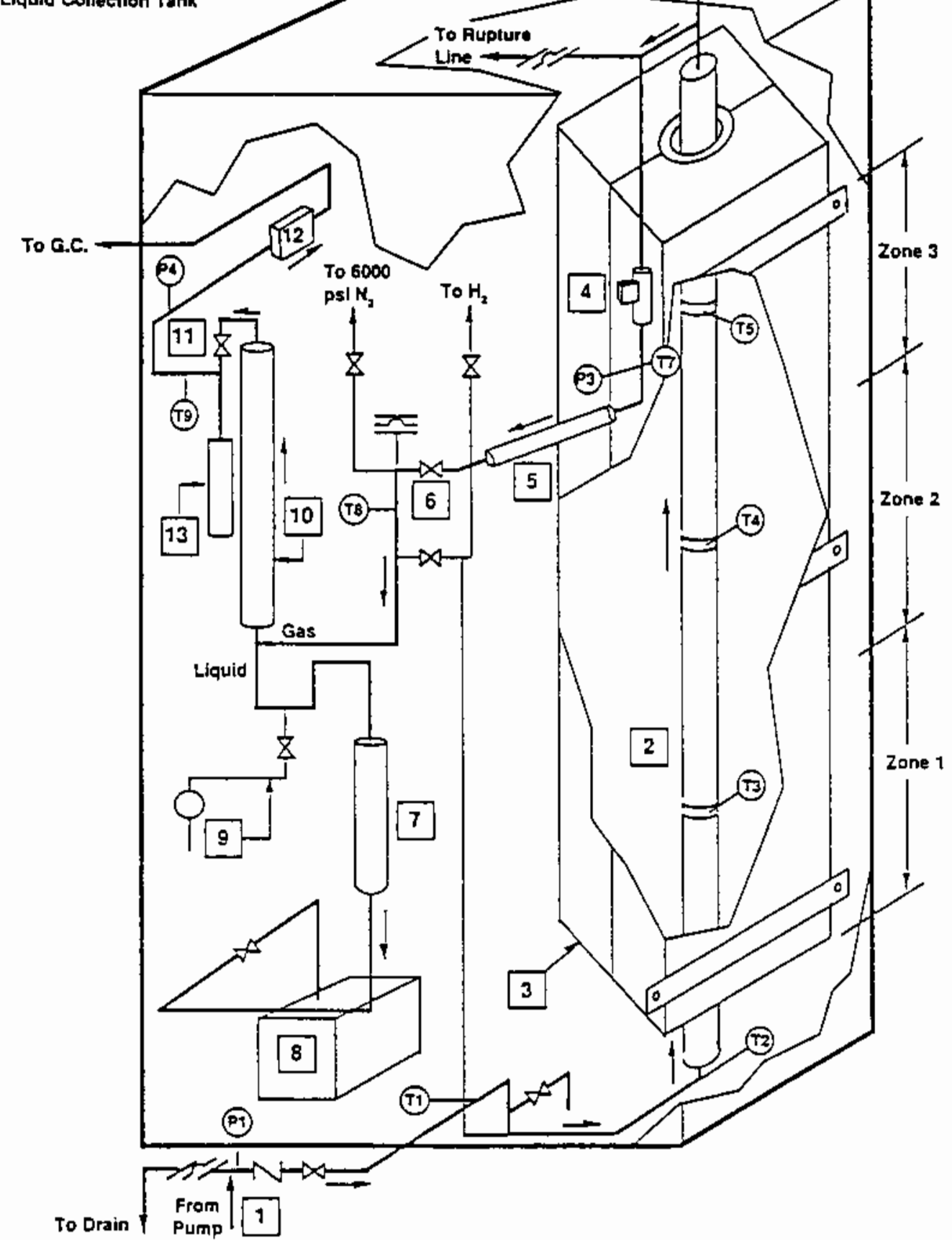

FIGURE 1. Continuous Reactor System 


\section{Reactor}

The reactor was a l-in. ID $\times 72$-in.-long 304 SS tube. The vessel had a maximum allowable working pressure of 10,000 psig at $22^{\circ} \mathrm{C}$, which derated to $5200 \mathrm{psig}$ at $450^{\circ} \mathrm{C}$. The vessel had bolted closure endcaps with metal 0 -rings on each end. Catalyst pellets were supported in the reactor on a circle of fine screen. The reactor furnace was a $6-\mathrm{kW}_{\mathrm{e}}$ resistance heater split into three separately controllable zones.

Pressure was controlled in the reactor by a Badger-Meter Research control valve and later a back-pressure regulator. Piping downstream from the reactor was 0.25-in. in diameter with thick-wa11 (0.049-in.) tubing upstream of the pressure letdown device and thin-wal1 (0.035-in.) tubing after pressure letdown. The Badger-Meter valve contained a $3 / 32$-in. orifice (trim size 0 ). The valve stem and seat were made of stellite.

Early experiments with the Badger Meter valve often resulted in premature termination of the experiment because of poor pressure control. The difficulty was attributed to wear at the seating ring caused by operating the system at low flow rates. A contributing factor was the movement of catalyst support materials (calcium and silica) out of the reactor and into the downstream lines and pressure control valve where they were deposited. Attempts with a smaller trim size (P6, 1/16-in. orifice) resulted in insufficient flow and pressure buildup in the reactor. The pressure control valve was later replaced with a dome-loaded diaphragm back-pressure regulator, which generally provided the required pressure control.

\section{Reaction Products Separation}

Separating the reaction products, which included an aqueous phase and (sometimes) a tar or 011 phase, in addition to the gaseous products, was a difficult task in the overall design of the reactor system. The downstream processing of the gas included quenching reactor products, separating liquid phases from the gaseous products, and sampling each phase for analysis. Gas analysis, considered the most critical element in determining reactor material balances, was performed on a continuous basis and via grab samples. 
Separation of phases was effected in a 24-in. $\times$ 0.5-in.-diameter tube, vertical secondary condenser/separator. Products were cooled in a primary condenser and reduced in pressure over the pressure control device before entering the separator. Although the secondary condenser was originally expected to significantly impact the cooling of the product stream, in most cases little secondary cooling was needed. A Balston Floattrap (Type 20-211) was placed after the secondary condenser to eliminate carryover of water into the offgas stream and flooding of the gas analysis system. A T-type filter (Balston Type 95S6) with a $0.02-\mu \mathrm{m}$ hollow fiber membrane filter was installed to back up the floattrap. The floattrap was self-draining, and the secondary condenser was drained manually. Condensate product from both drains was collected in a 1 iquid receiving tank, which was mounted on an electronic load cell with a \pm -g precision.

A liquid sample loop, upstream of the secondary condenser, allowed recovery of small volumes of liquid product before it was mixed in the condensate collecting vessel. These samples were believed to be representative of the reactor outlet contents.

\section{Instrumentation and Control}

The data acquisition and control (DAC) system employed in the CRS was a hybrid computer-based system employing discrete data acquisition devices and single loop process controllers communicating to a central computer via RS232 serial communications 1 ines. The system was described in detail in our earlier report [Elliott et a1. 1989]. The computer was used during experiments to monitor the process, calibrate instruments, and record data onto an ASCII disk file for later analysis. A custom-built, QuickBASIC program, revised from our earlier work, was used to coordinate these activities.

The gas analysis was performed by a Foxboro Model $931 \mathrm{C}$ industrial process gas chromatograph (GC), which is described elsewhere in this report. The Foxboro GC was tied to the computer through an RS232 serial interface. The cycle time on the Foxboro was roughly 5 min.

Noncontrol sensors such as thermocouples, pressure transducers, and the gas mass flowmeter were monitored via a Daytronics System 10 data acquisition 
unit. The Daytronics system processed all raw signals to engineering units before sending the data to the computer for recording.

\section{Safety Requirements}

Performing the high-pressure experiments demanded the careful development of the experimental reactor system and safe operating procedures. Before the experimental program was initiated, the high-pressure reactor system and the laboratory facility (where it is located) underwent a safety analysis and review, including evaluation of the equipment by staff members responsible for safety and pressure systems engineering. The Safety Evaluation Document for the facility was reviewed to assure that all safety concerns related to the tubular reactor configuration were addressed. Safe Operating Procedures were written specifically for the tubular reactor configuration. All appropriate quality assurance and safety procedures and guidelines concerning pressure vessel certification and operation were consulted and incorporated into the Standard Operating Procedures document.

Several safety features were built into the design, including specification of fail-safe valves to prevent overpressure situations in the case of control system failure; manual depressurizing capability; and use of relief valves and vented rupture discs. A steel barricade was built around critical components to further shield operators in the event of system failure.

An equally important step in ensuring operator safety was the requirement of a specialized safety training session for all potential operators. This session was developed in cooperation with PNL safety engineers. 
. 


\section{PROCEDURES}

This section discusses the procedures for operating the CRS and for analyzing the reaction feedstocks and products.

\section{CRS OPERATION}

The reactor was first loaded with the specified amount and type of catalyst, then sealed and the low-pressure end of the system pressure-checked with nitrogen. While the system was pressurized, the calibration of all system pressure transducers was verified by comparing their readouts with a calibrated mechanical gauge. The high-pressure end of the reactor system was then pressure-checked with nitrogen, and the purge gas was vented from the system. The initial supply of prepared feedstock was then loaded into the feed vessel.

The pump stroke length was set next, and the pump was primed. When the system had heated to operating temperature the feed was diverted into the reactor system by closing the priming valve. Feed rates, temperatures, and pressures were controlled throughout the experiment while products were recovered and quantified. Cooling water flow to the condensers was maintained throughout the experiment.

Several shutdown approaches were evaluated before a process was developed that would maintain the catalyst in an active state while idling the reactor system. Major activity loss occurred when the used catalyst was stored in a c001, wet condition ejther in hydrogen, inert gas, or air and when the catalyst was maintained at operating conditions whether or not the bed was purged with deionized water. The successful shutdown method ultimately developed involved purging the reactor by pumping deionized water through the bed until gas production had dropped to a low level and the aqueous products had a low chemical oxygen demand (COD) reading and neutral $\mathrm{pH}$. Then the reactor heaters were turned off, and the residual heat in the system was used to blow the water out of the catalyst bed by slowly reducing the pressure in the system. The reactor was maintained at $100 \mathrm{psig}$ and $200^{\circ} \mathrm{C}$ with a low flow of hydrogen to dry the catalyst and maintain its reduced state. 


\section{ANALYTICAL PROCEDURES}

A number of analytical procedures were required in this project to understand the complex gasification reactions occurring during the testing of feedstocks.

\section{Elemental Analysis}

A Perkin-Elmer (P-E) $240 B$ analyzer was used for carbon, hydrogen, and nitrogen. The P-E $240 \mathrm{~B}$ determined the amount of carbon, hydrogen, and nitrogen by detecting and measuring their combustion products $\left(\mathrm{CO}_{2}, \mathrm{H}_{2} \mathrm{O}\right.$, and $\left.\mathrm{N}_{2}\right)$. Combustion occurred in pure oxygen under static conditions. Helium was used to carry the combustion products from the combustion furnace through the reduction tube (which reduces any $\mathrm{NO}_{\mathrm{x}}$ ) and through a series of thermal conductivity detectors.

Aqueous COD Analysis

The aqueous feedstocks and products were analyzed for COD. The COD measurements were made with the HACH closed reflux micromethod. In this system, approved by the U.S. Environmental Protection Agency, prepackaged reagents are reacted with the sample. The proper amount of liquid effluent sample was added to a COD digestion reagent vial and then digested at $150^{\circ} \mathrm{C}$ for $2 \mathrm{hr}$. The COD was measured by placing the vial (after digestion) in a spectrophotometer and reading the COD from a calibrated scale that read directly in $\mathrm{mg} \mathrm{COD} / \mathrm{L}$.

\section{Gas Product Analysis}

Gas product analys is was used to determine material balances and conversion rates around the reactor system. The gaseous stream was composed principally of $\mathrm{CO}_{2}, \mathrm{CH}_{4}, \mathrm{H}_{2}, \mathrm{C}_{2}$, and $\mathrm{C}_{2}+$ hydrocarbons, as well as water vapor. The gas analysis equipment was able to measure these gas concentrations with reasonable accuracy and precision on a near-continuous (real-time) basis with a very short $(<5 \mathrm{~min})$ turnaround. This rapid turnaround was important to establishing steady-state operation during relatively limited duration experiments and helped in minimizing the assumptions made when determining material balances around the reactor. In the CRS, a thermal conductivity-based detector was used in a GC analyzer (Foxboro 931C). 
A secondary means of product gas analysis was by dedicated GCs for gas composition determination. Two separate Carle Automatic Gas Chromatographs were used. A thermal conductivity detector (Model 158A) was used to analyze gases, including hydrogen, carbon oxides, oxygen, nitrogen, methane, ethane, and ethylene. A flame ionization detector (Model 357A) was used to measure hydrocarbon vapor $\left(C_{1}\right.$ to $\left.C_{6}\right)$ concentrations. 
. 


\section{EXPERIMENTAL RESULTS}

The tubular reactor operations were an extension of the earlier CRS tests with the Carberry reactor. Initial system testing of the tubular reactor configuration began in August 1989 when water was processed through the reactor, which contained several types of nickel catalyst. This test was conducted to verify system operation and control. No major difficulties in the initial startup of the reactor system were encountered.

As indicated in the section on design components, during subsequent tests, pressure control problems with the Badger-Meter valve led to premature shut down of several experiments until a back-pressure regulator was installed. Loss of seating surface and/or deposits on the seating surface of the valve caused it to work improperly. However, a combination of factors were at the root of the problem. The flow rate used in the experiments resulted in the valve being nearly closed throughout the experiments. Major wear on the seating ring resulted. However, an additional significant factor was a change in plumbing from the Carberry reactor configuration which removed a 3 -ft vertical, upflow run of tubing immediately following the reactor. Replacing that tubing with a downward sloping run of tubing allowed easier movement of solid materials out of the reactor and into the valve. These materials primarily were components from the catalyst supports, such as calcium and silica. These materials were found after the aborted experiments as deposits in the product lines, filter, the aqueous condensate tank, and on the stem of the pressure control valve. Movement of these components out of the reactor also suggests an explanation for the catalyst softening seen in some cases.

\section{PROCESSING TEST RESULTS}

Twenty-nine separate CRS tests with ten different catalysts were completed in this reporting period mainly to evaluate catalyst operability. Operating conditions of pressure and temperature were varied only slightiy. Feedstock concentration and processing rate were the primary variables, other than feedstock and catalyst composition. A wide range of catalyst activities 
and stabilities were identified in this study. Suitable operating conditions were identified for high-conversion operation for all the feedstocks tested. The results from these tests are presented in Tables 2 through 6 , which are displayed under their respective subsections. The test numbers in the tables indicate the chronological order of the tests. Test numbers with lower case letters represent separate data windows within the same test. The data windows represent steady-state operating conditions of 1 to $5 \mathrm{hr}$ in length. Lactose Tests

Lactose was tested extensively as an inorganic-free model of cheese whey. Genera $11 y, 75 \%$ of the dry solids in cheese whey are lactose, and the dry solids yield $10 \%$ ash. The results in Table 2 show that a wide range of results were obtained with different catalysts in the reactor (compare tests $19,21,22$, and 23). The $\mathrm{Ni}-0750$ catalyst is the preferred catalyst based on these results. High conversion of $\mathrm{COD}$ and gas production was achieved. Shutdown of the catalyst bed and restart (without proper bed preparation, see CRS 0peration section in this report) caused a large loss in catalyst activity (compare test 19 with 20 ; test 26 with 27 ; and the two data sets from test 24). Test 21 provides a useful baseline test of catalytic effect of unreduced nickel. Low levels of gas production and methane synthesis occurred in that test, indicating that a primarily pyrolytic (noncatalytic) reaction was occurring.

Tests 22 and 23 provide an interesting comparison of two moderately active catalysts. At 0.8 to $0.9 \mathrm{~L} / \mathrm{hr}$ feed rates, both catalysts exhibit carbon conversion percentages in the mid-forties. The RKNR appears to have a slightly lower steam reforming activity but a slightly higher methanation activity. In neither case is the COD conversion equal to the carbon gasification; this difference implies carbon buildup in the catalyst bed. With the Cll catalyst, the pumping rate was slowed in order to increase residence time in the reactor, but the discrepancy between the two measurements only became worse. Eventually the catalyst bed was plugged with tar. With the RKNR catalyst, the pumping rate was increased, which caused the gasification to be reduced somewhat, while the discrepancy between carbon gasification and COD conversion disappeared. Based on these results, it appears that a minimum 
TABLE 2. Test Results of Nickel-Catalyzed Gasification of Lactose

\begin{tabular}{|c|c|c|c|c|c|c|c|c|c|c|c|c|c|}
\hline 19 & 20 & 21 & $22 a$ & $22 b$ & $23 a$ & $23 b$ & $24 a$ & $24 b$ & $26 a$ & $26 \mathrm{~b}$ & $26 \mathrm{c}$ & $26 \mathrm{~d}$ & 27 \\
\hline
\end{tabular}

Catalyst

Ni-0750 used ${ }^{(a)}$ R-67 C11-9-64 same ${ }^{(b)}$ RKIR same ${ }^{(b)} N i-0750$ used $^{(a)}$ Ni-9750 same same $^{(b)}$ same $^{(b)}$ used ${ }^{(a)}$

Feed, wt\% dry solids , g COO/L

16

$10 \quad 10 \quad 16 \quad 100$

$10 \quad 10 \quad 10$

$5^{(c)} \quad 5^{(c)}$

Feed Rate, L/hr , g coD/hr

$111 \quad 162$

$183 \quad 166$

$\begin{array}{lll}10 & 18 & 16 \\ 186 & 117 & 117\end{array}$

$5(c)$
54

$5^{(c)}$
52

5
56

5

5

$\begin{array}{ll}5 & 5 \\ 56 & 56\end{array}$

$\begin{array}{llll}0.96 & 0.41 & 0.57 & 9.80 \\ 107 & 41.8 & 58.7 & 84.8\end{array}$

$\begin{array}{llll}0.26 & 0.87 & 1.40 & 1.18\end{array}$

$1.14 \quad 1.23$

$\begin{array}{llll}1.20 & 1.56 & 1.12 & 1.19\end{array}$

Effluent, mg $\cos / \mathrm{t}$

$530 \quad 22000 \quad 46000 \quad 12260$

$11000 \quad 30500 \quad 76006 \quad 440$

Reduct ín of COD, $z$

99.3

$80.8 \quad 68.1 \quad 69.5$

$94.7 \quad 76.6 \quad 38.0$

99.2

$10200 \quad 199$

67.

Carbon Conversion

$\begin{array}{llll}88.5 & 40.2 & 15.2 & 46.7\end{array}$

$\begin{array}{llll}28.3 & 43.4 & 34.7 & 99.9\end{array}$

$81.4 \quad 99.7$

99.8

B7.4 56.0

to Gas, $x$

Gas Composition, vol $\%$

\begin{tabular}{|c|c|c|c|c|c|c|c|c|c|c|c|c|c|c|}
\hline methane & 47.5 & 21 & 3 & 20.3 & 18 & 25 & 27 & 44 & 23 & 41.5 & 39 & 29 & 26 & 20 \\
\hline carbon dioxide & 49.2 & 70 & 83 & 52.1 & 56 & 49 & 46 & 48 & 53 & 46.5 & 47 & 53.5 & 47 & 50 \\
\hline hydrogen & 2.5 & 4.7 & 12 & 24.2 & 26 & 24 & 24 & 7.0 & 21 & 9.5 & 19 & 10.5 & 21 & 22 \\
\hline ethane & 0.4 & 1.5 & 0.5 & 9.6 & 9.4 & 0.7 & 0.7 & 1.0 & 1.1 & 1.7 & 2.2 & 3 & 3 & 3 \\
\hline$c_{3}-c_{4}$ & B. 3 & 2.8 & 2.2 & 1.1 & 0.8 & 1.6 & 2.0 & 0.4 & 1.8 & 0.8 & 1.0 & 2.8 & 3.1 & 4.8 \\
\hline $\mathrm{Btu} / \mathrm{SCF}$ & 509 & 341 & 145 & 334 & 298 & 392 & 425 & $5 \$ 2$ & 375 & 566 & 513 & 496 & 478 & 472 \\
\hline Yíeld, L/g solids & 0.70 & 9.30 & 0.13 & B. 46 & 0.29 & 0.42 & B. 33 & 9.78 & 8.54 & 9.79 & 0.77 & 0.64 & 9.77 & 9.61 \\
\hline . SCF/dry lb & 11.2 & 4.8 & 2.1 & 7.4 & 4.6 & 6.7 & 5.3 & 12.5 & 8.6 & 12.7 & 12.3 & 10.2 & 12.3 & 9.8 \\
\hline Batance, $\%$ & 96.6 & 93.8 & 84.4 & 97.3 & 55.1 & 95.0 & 99.4 & 97.8 & 98.4 & 98.2 & 95.8 & 97.8 & 98.1 & 97.1 \\
\hline
\end{tabular}

(a) "Used" = same catalyst charge tested following shutdown and startup of the reactor after 1 or more days.

(b) "Same" = same catalyst charge tested at different flow rate during same day.

(c) $5 \%$ lactose $+1 \%$ sodium carbonate. 
velocity (between 0.9 and $1.4 \mathrm{~L} / \mathrm{hr}$ ) is required to properly move the feedstock through the reactor to achieve sufficient mixing and contact with the catalyst and to prevent precipitation of feedstock or intermediates in the catalyst bed. Long-term operation in test 26 showed that a feed rate of $1.2 \mathrm{~L} / \mathrm{hr}$ is sufficient.

Tests $26 / 27$ were a continuous operation of $48 \mathrm{hr}$ followed by a shutdown and restart of the reactor after 3 days. Stable operation was achieved at $1.2 \mathrm{~L} / \mathrm{hr}$ as shown in Table 2 (tests 26a,b). Operation at a higher feed rate resulted in insufficient residence time and reduced conversion and gasification (test 26c). Upon return to the original feed rate, nearly full recovery of catalyst activity was achieved (test 26d), although gradual loss of activity continued until the test was shut down. Idling the wet catalyst bed over the weekend caused significant loss of catalyst activity which was evident upon restart of the reactor (test 27).

Test 24 was performed to determine the effect of alkali on the catalytic system. An operating hypothesis was that the addition of sodium carbonate could modify the activity of the nickel catalyst to improve the reaction rate or to maintain the high reaction rate seen in the early stages of the tests as described above. Comparing the results in test 24 with test 26 suggests that there was little effect of alkali on the process results.

\section{Cheese whey Tests}

Although the lactose tests were helpful in understanding the mechanics of the reactor operation and in identifying useful catalysts for the process, the feedstock of interest was cheese whey. Results with several catalysts are given in Table 3. Similar processing rates were achieved with the cheese whey as with the lactose. Again, the Ni-0750 catalyst was the most active. Both the $\mathrm{Ni}-3210$ and the (46-7-03 catalysts (tests 16 and 18 ) experienced rapid loss of catalyst activity over the first hours in the test until the levels listed in Table 3 were reached, while the $C 150$ catalyst (test 29) was somewhat more stable and active. Evidence of silica migration into the downstream piping was noted after the 146 test. 
IABLE_3. Test Results of Nickel-Catalyzed Gasification of Cheese Whey

$16 \mathrm{~d}-16 \mathrm{~b}-16 \mathrm{c}+18 \mathrm{a}-18 \mathrm{~b}-18 \mathrm{c}-18 \mathrm{~d}-28 \mathrm{a}-26 \mathrm{~b}-28 \mathrm{c}-28 \mathrm{~d}-29 \mathrm{a}-29 \mathrm{~b}-36 \mathrm{a}-36 \mathrm{~b}-36 \mathrm{c}-36 \mathrm{~d}$

\begin{tabular}{|c|c|c|c|c|c|c|c|c|c|c|c|c|c|c|c|c|c|}
\hline Catalyst & $\frac{160}{c 46-7-83}$ & $\frac{16 b}{\text { same }^{(b)}}$ & $\frac{16 c}{\operatorname{same}^{(b)}}$ & $\frac{18 a}{11 i-3218}$ & $\frac{18 b}{\text { same }}$ & $\frac{18 c}{\text { same }}$ & $\frac{18 \mathrm{~d}}{\text { used }^{(a)}}$ & $\frac{28 \mathrm{a}}{\mathrm{Ni-6750}}$ & 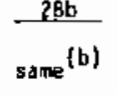 & $\frac{28 c}{\text { used }^{(a)}}$ & $\frac{2 B d}{\operatorname{sane}^{(b)}}$ & $\frac{29 a}{c 150}$ & ${ }_{\text {used }^{(a)}}^{-29 \mathrm{~b}}$ & $\frac{360}{M i-0750}$ & $\frac{36 b}{s_{\text {sane }}^{(b)}}$ & $\frac{36 c}{\text { used }^{(a)}}$ & $\frac{36 d}{\text { same }}$ \\
\hline $\begin{array}{l}\text { Feed. wtZ dry sollds } \\
\text { g } \operatorname{coD} / L\end{array}$ & $\begin{array}{l}6.4 \\
71\end{array}$ & $\begin{array}{l}6.4 \\
71\end{array}$ & $\begin{array}{l}6.4 \\
71\end{array}$ & $\begin{array}{l}\text { B. } 4 \\
68\end{array}$ & $\begin{array}{l}6.4 \\
68\end{array}$ & $\begin{array}{l}8.5 \\
90\end{array}$ & $\begin{array}{l}118 \\
125\end{array}$ & $\begin{array}{l}6 \\
67\end{array}$ & $\begin{array}{l}6 \\
67\end{array}$ & $\begin{array}{l}6 \\
65\end{array}$ & $\begin{array}{l}6 \\
65\end{array}$ & $\begin{array}{l}6.3 \\
63\end{array}$ & $\begin{array}{l}6.3 \\
63\end{array}$ & 4 & 46 & $\begin{array}{l}4 \\
49\end{array}$ & $\begin{array}{l}4 \\
49\end{array}$ \\
\hline $\begin{aligned} \text { Feed Rate, } \mathrm{L} / \mathrm{hr} \\
\text {, } \mathrm{gCOD} / \mathrm{hr}\end{aligned}$ & $\begin{array}{l}1.12 \\
79.5\end{array}$ & $\begin{array}{l}0.61 \\
43.5\end{array}$ & $\begin{array}{l}0.95 \\
67.5\end{array}$ & $\begin{array}{l}1.19 \\
74.8\end{array}$ & $\begin{array}{l}6.53 \\
35.9\end{array}$ & $\begin{array}{l}0.58 \\
45.8\end{array}$ & $\begin{array}{l}0.5 \\
62.5\end{array}$ & $\begin{array}{l}1.16 \\
77.7\end{array}$ & $\begin{array}{l}1.18 \\
79.4\end{array}$ & $\begin{array}{l}1.16 \\
75.4\end{array}$ & $\begin{array}{l}1.47 \\
95.6\end{array}$ & $\begin{array}{l}1.24 \\
78.1\end{array}$ & $\begin{array}{l}1.17 \\
73.7\end{array}$ & $\begin{array}{l}1.31 \\
66.3\end{array}$ & $\begin{array}{l}1.48 \\
64.4\end{array}$ & $\begin{array}{l}1.34 \\
65.7\end{array}$ & $\begin{array}{l}1.48 \\
72.5\end{array}$ \\
\hline Effluent, $\mathrm{mg} \mathrm{COO} / \mathrm{L}$ & 16750 & 16960 & 17800 & 13358 & 10938 & 15500 & 26000 & 360 & 485 & 11608 & 19060 & 9680 & 1980 v & 490 & 245 & $3 / 0$ & 910 \\
\hline Reduction of $\cos , x$ & 77.4 & 79.1 & 75.3 & 81.7 & 84.6 & B3.2 & 79.5 & 99.5 & 99.3 & 82.8 & 71.9 & 86.3 & 78.2 & 99.0 & 99.5 & 99.3 & $9 \theta .3$ \\
\hline $\begin{array}{c}\text { Carban Conversion } \\
\text { to Gas, I }\end{array}$ & 55.1 & 47.6 & 48.7 & 66.6 & 55.2 & 36.1 & 21.8 & 99.1 & 97.6 & 66.2 & $5 t .5$ & 87.9 & 61.4 & 108.3 & 99.5 & 93.8 & 93.3 \\
\hline
\end{tabular}

Gas Compas it lan, val $x$

\begin{tabular}{|c|c|c|c|c|c|c|c|c|c|c|c|c|c|c|c|c|c|}
\hline methane & 21 & 23 & 21 & 37 & 12 & 37 & 28 & 48 & 44.5 & $2 \theta .5$ & 22 & 33.5 & 27 & 53 & 54 & 52 & 52 \\
\hline carbon dioxide & 52 & 57 & 59 & 46 & 43 & 5) & 65 & 44.5 & 46 & 48 & 51 & 46 & 53 & 43 & 41 & 43 & 43 \\
\hline hydrogen & 26 & 18 & 15 & 19 & 9.7 & 6.4 & 7.5 & 5.5 & 7.0 & 26.5 & 24 & 18 & 17 & 2.4 & 2.2 & 2.7 & 2.6 \\
\hline ethane & 1.1 & 0.7 & 1.6 & 1.2 & 1.5 & 1.3 & 1.6 & 1.0 & 1.1 & 1.2 & 1.1 & 1.1 & 1.2 & 1.2 & 1.2 & 1.1 & 1.1 \\
\hline$c_{3}-c_{4}$ & 1.7 & 1.4 & 2.3 & 2.0 & 2.6 & 2.8 & 3.8 & 0.9 & 1.2 & 1.8 & 1.8 & 1.6 & 1.8 & 0.4 & 9.8 & 1.2 & 1.1 \\
\hline Btu/SCF & 369 & 347 & 361 & 522 & 565 & 508 & 374 & 549 & 529 & 430 & $3 / 4$ & 465 & 404 & 578 & 604 & $59 !$ & 588 \\
\hline $\begin{array}{r}\text { Yield. L/g solids } \\
\text { scF/dry lb }\end{array}$ & $\begin{array}{l}0.58 \\
8.8\end{array}$ & $\begin{array}{l}0.48 \\
6.4\end{array}$ & $\begin{array}{l}0.38 \\
6.1\end{array}$ & $\begin{array}{l}0.55 \\
8.8\end{array}$ & $\begin{array}{l}0.40 \\
6.4\end{array}$ & $\begin{array}{l}8.25 \\
4.6\end{array}$ & $\begin{array}{l}0.22 \\
3.5\end{array}$ & $\begin{array}{l}0.68 \\
16.9\end{array}$ & $\begin{array}{l}9.66 \\
10.6\end{array}$ & $\begin{array}{l}0.50 \\
8.8\end{array}$ & $\begin{array}{l}0.40 \\
6.4\end{array}$ & $\begin{array}{l}0.59 \\
9.4\end{array}$ & $\begin{array}{l}9.41 \\
6.6\end{array}$ & $\begin{array}{l}0.10 \\
11.2\end{array}$ & $\begin{array}{l}0.72 \\
11.5\end{array}$ & $\begin{array}{l}0.69 \\
11.6\end{array}$ & $\begin{array}{l}0.68 \\
18.9\end{array}$ \\
\hline Balance. $x$ & 106.8 & 96.2 & 106.5 & 97.3 & 99.0 & 100.3 & 100.5 & 100.6 & 99.8 & 100.2 & 99.2 & 186.5 & 182.1 & 92.5 & 96.2 & 95.3 & 95.3 \\
\hline
\end{tabular}

(a) "Used" = same catalyst charge tested following shutdown and startup of the reactor of ter 1 or mare days.

(b) "Same" - same catalyst charge tested at different flow rate during same day. 
Shutdown and restart of the $\mathrm{Ni}-0750$ catalyst was demonstrated in test 36 wherein high conversion rates, gas yields, and methane production were achieved on 2 successive days of operation with a shutdown overnight in between. Earlier attempts at restart without the preparatory procedure resulted in major loss in activity (compare tests $18 \mathrm{c}$ and $18 \mathrm{~d}, 28 \mathrm{~b}$ and $28 \mathrm{c}$, or 29a and 29b). Following the extended test 36, white deposits, which appeared to be calcium salt from the cheese whey, were found in the catalyst bed. This material may be removed from the bed by higher velocity operation similar to the tar buildup problem discussed above.

\section{Phenol Tests}

Phenol solutions in water were tested as feedstocks for the process both as a potential chemical waste stream and as a model of the chemical intermediates from pyrolysis of food processing wastes in the low-temperature gasification process. Results of these tests are given in Table 4. Two catalysts other than the $\mathrm{Ni}-0750$ were tested; both exhibit activity but at a lower leve1. Shutdown and restart of the 649 catalyst had only moderate deactivating effect (compare test $17 \mathrm{~b}$ and $17 \mathrm{~d}$ ), even though it was not properly prepared. The moderate deactivation was also a positive result considering that the catalyst had been run in an overload state as well (test $17 \mathrm{c}$ ).

The Ni-0750 test series (tests 32 through 35 ) showed that even multiple shutdown and restart of the catalyst bed could be accomplished without serious deactivation of the catalyst if proper bed preparation was used (compare test $32 b$ with $33 a$ and test $33 c$ with $34 a$ ). The test $35 a$ data follow a high-COD feed test with pyrolyzate condensate water. Apparently, operation with the pyrolyzate caused a major amount of catalyst deactivation, so that subsequent operation with phenol as the feedstock produced poor results. Comparing the COD processing rates and COD conversion percentages in Table 4 with Table 2 or 3 , it is obvious that the phenol reacted much more readily than the carbohydrate feedstocks. Because of its higher carbon to oxygen ratio, the phenol also produced a much higher ratio of methane to carbon dioxide.

The PK-5 test (tests 37a-e) demonstrate both the high conversion of phenol achieved at lower flow rates and concentrations (tests $37 \mathrm{a}$ and b) and al so the catalyst limitation at higher flow rate (tests $37 \mathrm{c}-\mathrm{e}$ ). Operation of 
TABLE 4. Test Results of Nickel-Catalyzed Gasification of Phenol

\begin{tabular}{|c|c|c|c|c|c|c|c|c|c|c|c|c|c|c|c|c|c|}
\hline \multicolumn{18}{|c|}{ Iest Humber } \\
\hline \multirow[b]{2}{*}{ Catalyst } & $-17 a$ & $17 b$ & $17 c$ & 170 & $17 \mathrm{e}$ & $32 \mathbf{a}$ & $32 b$ & $33 a$ & $33 b$ & $33 c$ & $34 \not$ & $35 a$ & $37 \mathrm{a}$ & 376 & $37 \mathrm{c}$ & $37 \mathrm{~d}$ & $37 \mathrm{e}$ \\
\hline & 649 & $\operatorname{sane}^{(b)}$ & same $^{(b)}$ & used $^{(a)}$ & same $^{(b)}$ & $\mathrm{Ni}-9750$ & same $^{(b)}$ & used $^{(a)}$ & same ${ }^{(b)}$ & same $^{(b)}$ & used $^{(a)}$ & used $^{(a)}$ & PK-5 & $\operatorname{same} e^{(b)}$ & used & same $e^{(b)}$ & same $^{(b)}$ \\
\hline \multirow{2}{*}{$\begin{array}{l}\text { Feed, wt\% dry solids } \\
\text {, g cod/L }\end{array}$} & 5 & 5 & 5 & 5 & 5 & 4.5 & 4.5 & 4.5 & 4.5 & 4.5 & 4.5 & 4.5 & 1.8 & 1.8 & 1,8 & 1.8 & 1.8 \\
\hline & 128 & 121 & 121 & 117.5 & 117.5 & 107.5 & 107.5 & 107.5 & 107.5 & 187.5 & 107.5 & 167.5 & 42.75 & 42.8 & 48.5 & 48.5 & 48.5 \\
\hline \multirow{2}{*}{ Feed Rate, $\begin{aligned} & \mathrm{L} / \mathrm{hr} \\
& \text {. } \mathrm{COOD} / \mathrm{hr}\end{aligned}$} & 1.18 & 1.57 & 2.11 & 1.21 & 0.66 & 1.09 & 1.55 & 1.64 & 1,99 & 1.62 & 1.67 & 1.15 & 1.05 & 1.53 & $1.6]$ & 2.05 & 1.71 \\
\hline & 141.5 & 190.8 & 255.3 & 142.2 & 78.0 & 117.2 & 166.6 & 176.3 & 213.9 & 174.2 & 179.5 & 123.6 & 44.9 & 65.5 & 78.1 & 99.4 & 85.8 \\
\hline \multirow{2}{*}{$\begin{array}{l}\text { Effluent, mg } \mathrm{COO} / \mathrm{L} \\
\text { Reduction of } \mathrm{coO}, \mathrm{z}\end{array}$} & 1990 & 3750 & 34000 & 12000 & 6100 & 34 & 54 & 62 & 748 & 650 & 350 & 21060 & 10 & 67 & 138 & 1250 & 595 \\
\hline & 98.6 & 97.3 & 74.3 & 89.8 & 94.5 & 99.97 & 99.95 & 99.95 & 99.4 & 99.5 & 99.7 & 82.4 & 99.8 & 99.9 & 99.8 & 97.6 & 98.8 \\
\hline \multirow{2}{*}{\multicolumn{2}{|c|}{$\begin{array}{l}\text { Carbon Conversion } \\
\text { to Gas, } x \\
\text { Gas Composition, yal } x\end{array}$}} & 74.2 & 44.3 & 65.4 & 79.2 & 99.2 & 98.9 & 99.5 & 92.0 & 94.3 & 92.7 & 47.5 & 99.8 & 186.0 & 96.2 & 83.7 & 86.9 \\
\hline & & & & & & & & & & & & & & & & & \\
\hline methane & 52 & 51 & 46 & 44 & 30 & 54.4 & 55 & 54.5 & 51.8 & 52.0 & 52.2 & 38 & 51 & 55 & 56 & 51.9 & 53 \\
\hline carbon dfoxlde & 39 & 40 & 42 & 48 & 38.5 & 39.5 & 46 & 40.4 & 41.2 & 41.2 & 41.2 & 45 & 48 & 41 & 39.5 & 41.7 & 41 \\
\hline hydrogen & 6 & 6 & 5. B & 11 & 22 & 4.7 & 3.1 & 2.8 & 3.5 & 3.4 & 3.4 & 4.2 & 7.5 & 2.3 & 2.5 & 2.8 & 2.6 \\
\hline ethane & 0.4 & 0.7 & $1 . \theta$ & 8.8 & 9.8 & 8.2 & 6.5 & 0.8 & 1.0 & l. 1 & a. 9 & 1.9 & a. 5 & 0.5 & 0.6 & 8.8 & 0.7 \\
\hline$c_{3}-c_{4}$ & 1.6 & 2.2 & 5.2 & 3.8 & 4.6 & 8.3 & B. 8 & 1.5 & 2.6 & 2.6 & 2.8 & 8.4 & 0.7 & 6.8 & 1.3 & 1.6 & 1.4 \\
\hline Btu/SCF & 584 & 614 & 658 & 669 & $51 B$ & 585 & 605 & 620 & 628 & 635 & 618 & 795 & 571 & 600 & 626 & 652 & $63 \mathrm{~b}$ \\
\hline Gas Yield, $L / g$ solids & 1.29 & 1.86 & 8.58 & 0.94 & 1.25 & 1.47 & 1.42 & 1.38 & 1.26 & 1.29 & 1.29 & 0.52 & 1.49 & 1.51 & 1.36 & 1.11 & 1.18 \\
\hline SCF/dry to & 20.8 & & 9.3 & .1 & 28.8 & 23.6 & 22.8 & 22.1 & 20.2 & 23.7 & 20.7 & 8.3 & 23.9 & 24,2 & 21.8 & 17.8 & 18.9 \\
\hline Mass Balance. $\chi$ & 94.4 & 93.8 & 95.1 & 185.7 & 105.4 & 97,7 & 97.4 & 97.6 & 97.2 & 96.7 & 99.8 & 93.8 & 94.8 & 95.7 & 97.6 & 95.9 & 98.1 \\
\hline
\end{tabular}

(a) "Used" = same catalyst charge tested following shutdown and startup of the reactor after 1 or more days.

(b) "Same" = same catalyst charge tested at different flow rate during same day. 
this moderately active catalyst apparently should be 1 imited to $1.5 \mathrm{~L} / \mathrm{hr}$ and probably less if higher concentrations of feedstock are processed. The effect of restart of the catalyst bed is not clear, since only higher flow rates were tested on the second day of operation.

\section{Spent Grain Tests}

Only a limited amount of work has been completed with spent grain as a feedstock in the tubular reactor. The results are shown in Table 5. Unfortunately, these results are only with one catalyst, PK-5, a moderately active catalyst, as seen in the phenol tests. The tests were run with insufficient residence as shown by low conversion and gasification. Loss of activity after shutdown and restart may also be a problem. Comparing these results with the phenol results in Table 4, clearly the spent grain is much less reactive in the low-temperature gasification system when using the moderately active PK-5 catalyst.

The difference between the $C O D$ conversion and the carbon gasification suggests a holdup of organics in the reactor (tar precipitation problem), as discussed earlier. The remedy for this problem is to provide faster velocity through the reactor, which will require a longer reactor in order to provide sufficient residence time.

\section{Para-Cresol, Hexone, and Sucrose Tests}

Other chemicals tested in the tubular reactor system were para-cresol, hexone (methylisobutylketone), and sucrose. Results of these tests are given in Table 6. The first two chemicals are models from earlier chemical waste studies, and the results of the current tests can be compared with earlier Carberry reactor test results [Baker et a1. 1989b]. The sucrose was tested here as a model of carbohydrate structures found in food processing wastes.

The results with para-cresol are similar to those with phenol. High processing rates with the $\mathrm{Ni}-0750$ catalyst produced high gas yields with strong methanation and $\mathrm{COD}$ conversion. Nearly complete conversion to gas was achieved at up to $2 \mathrm{~L} / \mathrm{hr}$ feed rate. However, the para-cresol was fed at a lower concentration, which was limited by its solubility in water at ambient feeding conditions. Higher concentrations of methane were found in the 
IABLE 5. Test Results of Nickel-Catalyzed Gasification of Spent Grain

Cataiyst

Feed, wt\% dry solids

, g COD/L

Feed Rate, L/hr , g $\operatorname{coD} / \mathrm{hr}$

Eff1uent, mg COD/L

Reduction of $\mathrm{COD}, \%$

Carbon Conversion

to Gas, \%

Gas Composition, vol \%

methane

carbon dioxide

hydrogen

ethane

$\mathrm{C}_{3}-\mathrm{C}_{4}$

Btu/SCF

Gas Yield, L/g solids

$$
\text { , SCF/dry } 1 \mathrm{~b}
$$

Mass Balance, \%
Test Number

\begin{tabular}{|c|c|c|c|}
\hline$\frac{38 a}{P K-5}$ & $\frac{38 b}{\text { same }^{(b)}}$ & $\frac{39 a}{\text { used }(a)}$ & $\frac{39 b}{\text { same }^{(b)}}$ \\
\hline 2.2 & 2.2 & 1 & 1 \\
\hline 35.5 & 35.5 & 19.25 & 19.25 \\
\hline 1.45 & 1.45 & 1.34 & 0.83 \\
\hline 51.5 & 51.5 & 25.8 & 16.0 \\
\hline 1080 & 11000 & 690 & 450 \\
\hline 97.1 & 69.9 & 96.4 & 97.8 \\
\hline 59.3 & 58.3 & 40.4 & 44.2 \\
\hline
\end{tabular}

$\begin{array}{llll}48 & 47 & 46 & 45 \\ 46 & 46 & 44 & 47 \\ 2.2 & 2.6 & 5.5 & 3.6 \\ 1.2 & 1.6 & 1.7 & 1.3 \\ 1.7 & 2.9 & 2.6 & 1.4 \\ 571 & 600 & 592 & 542\end{array}$

$\begin{array}{llll}0.52 & 0.50 & 0.36 & 0.40\end{array}$

$\begin{array}{llll}8.3 & 8.0 & 5.8 & 6.4\end{array}$

$\begin{array}{llll}96.7 & 98.8 & 100.6 & 94.9\end{array}$

(a) "Used" = same catalyst charge tested following shutdown and startup of the reactor after 1 or more days.

(b) "Same" = same charge tested at different flow rate during same day.

product gas because of the higher ratio of carbon to oxygen in the feedstock. The G-65B catalyst exhibited similarly high catalytic activity, while the RKNR catalyst had a lesser level of activity. Shutdown and restart of the G-65B catalyst (in an unprepared state) caused a significant loss in activity, and upon further operation, the catalyst showed continued rapid loss of activity. The RKNR showed some loss of activity during shutdown and restart but showed more stability than other catalysts without proper preparation. 
TABLE 6. Test Results of Nickel-Catalyzed Gasification of Para-Cresol (tests $12,13,25,30$ ), Hexone (test 31), and Sucrose (test 15)

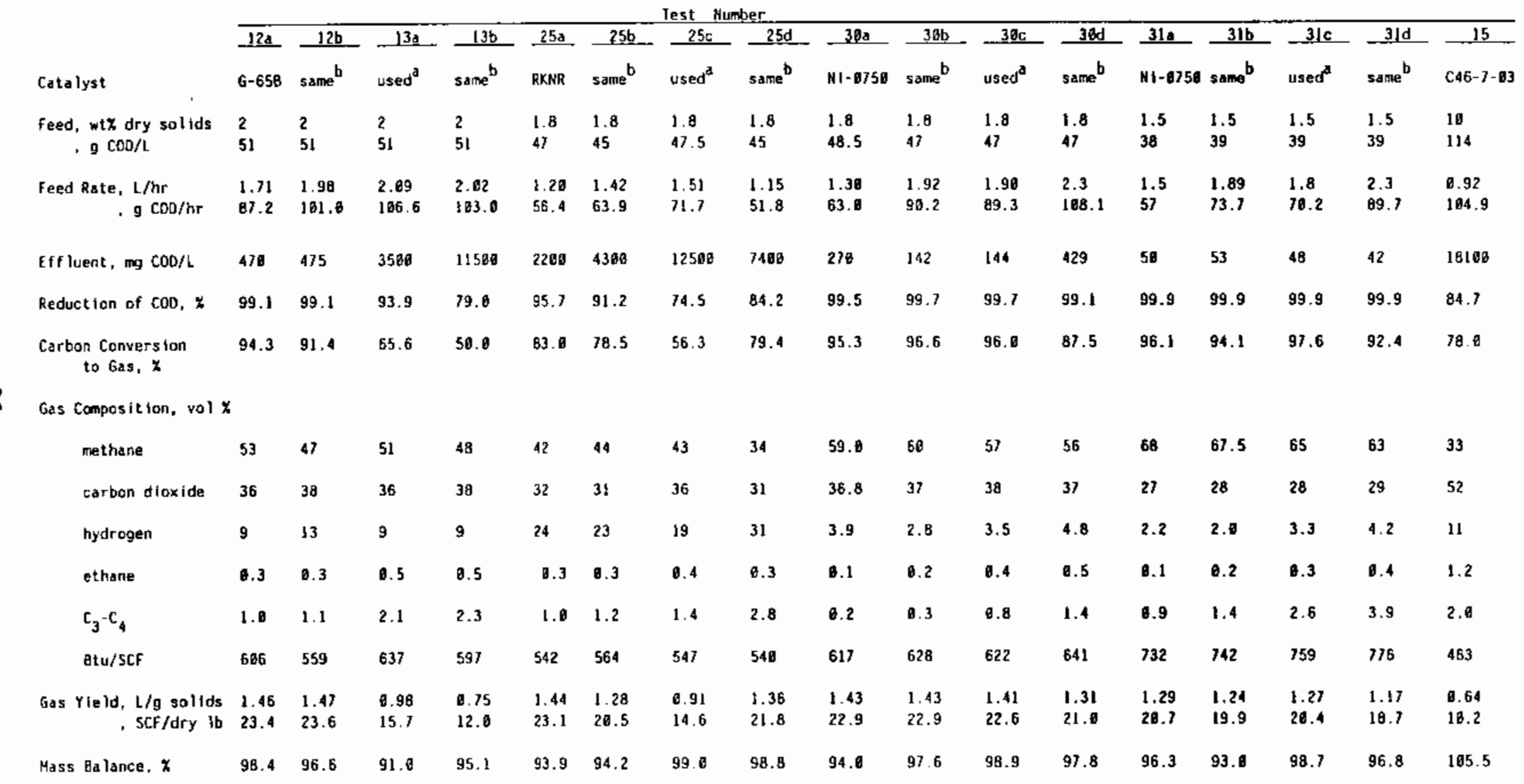

(a) "Used" = same catalyst charge tested following shutdown and startup of the reactor after 1 or more days.

(b) "Same" = sane catalyst charge tested at different flow rate during sane day. 
Hexone was the most readily gasified feedstock tested in these studies. With the $\mathrm{Ni}-0750$ catalyst, nearly complete conversion of $\mathrm{COD}$ to gas was achieved at up to $2.3 \mathrm{~L} / \mathrm{hr}$. At that rate, the COD of the product water was as low as at any other rate, implying that further rate increases could be achieved. However, the slight drop in gas yield did not corroborate this implication.

Two early tests were performed with sucrose as the feedstock. The first was aborted when the pressure control valve failed. Upon restart, the catalyst had little activity. The second, listed in Table 6 , was done with the C46 catalyst. Only moderate activity was exhibited at low flow rates.

\section{BATCH EXPERIMENTS}

A series of five batch reactor experiments were performed to test experimental catalysts for comparison with the conventional nickel methanation/hydrogenation catalysts used in this process. The batch reactor used is that described in our earlier report [Sealock et a1. 1988]. Some of the results from these experiments are given in Table 7 . None of the catalysts tested were useful except the RKNR.

The $\mathrm{Zr} / \mathrm{Ni}$ catalyst was an experimental zirconia-nickel oxide powder produced by a proprietary process at PNL. The material had to be reduced in situ in the batch reactor before the gasification experiment. Little reduction was apparent, so we believe the material was used in the gasification test essentially as an oxide. As described above, nickel oxide is not a catalyst for this gasification system. Further tests with a reduced powder might produce an active catalyst.

The two inactive ruthenium catalysts, $1 \%$ ruthenium on carbon and $0.5 \%$ ruthenium on alumina spheres, may also have been unreduced. In their manufacturing process, they underwent a moderate reduction (sufficient for most conventional uses of the catalyst), which was described by the manufacturer as producing a suboxide and not a truly metallic state. Further reduction to the active metallic form may not have been achieved in our reactor system and may explain the lack of activity. 
TABLE 7. Results from Batch Reactor Experiments with Different Catalysts

\begin{tabular}{|c|c|c|c|c|c|}
\hline & ZrNi & RKNR & $\mathrm{Pd}$ & $\underline{\mathrm{Ru} / \mathrm{C}}$ & $\begin{array}{l}\mathrm{Ru} / \mathrm{Al} \\
\text { Sphere }\end{array}$ \\
\hline Carbon Conversion to Gas, $\%$ & 1.7 & 24.3 & 0.1 & 4.5 & 0.2 \\
\hline \multicolumn{6}{|c|}{ Nitrogen-free Product Gas Composition } \\
\hline methane, vol\% & 1.6 & 29.8 & 0.0 & 22.7 & 8.9 \\
\hline carbon dioxide, vo $1 \%$ & 69.6 & 29.6 & 53.8 & 45.5 & 28.7 \\
\hline hydrogen, vol\% & 28.5 & 38.8 & 44.5 & 27.5 & 62.4 \\
\hline
\end{tabular}

70 min at $350^{\circ} \mathrm{C}$, autogenic pressure $(170-272 \mathrm{~atm}), 10 \%$ para-cresol in water.

The $0.5 \%$ palladium catalyst was formed on a ka0lin support. The catalyst powder was found cemented into a lump on the bottom of the reactor following the experiment. Apparently, the kaolin reacts and agglomerates in our system. 


\section{DISCUSSION OF RESULTS}

The CRS tests run with the tubular reactor provided useful information on catalyst effects and process kinetics.

\section{CATALYST EFFECTS}

The major portion of the research for this report has been focused on the catalyst for the process. Although the main concern at the beginning of this study was the effect of contaminants in the feedstocks on the catalyst, this effort has concentrated on the stability of the catalyst itself under reactor conditions.

Maintaining the catalyst activity is of paramount importance in any catalytic process. The successful use of the nickel metal catalyst in the TEES reaction environment is a priority in this research. Batch tests [Sealock et a1. 1981; Elliott and Sealock 1985; Elliott, Butner, and Sea]ock 1988; Sealock et al. 1988; Baker and Sealock 1988] demonstrated the shortterm activity of the catalyst; initial CRS experiments [E1]iott et al. 1989; Baker et al. 1989a; Baker et a1. 1989b] identified catalyst stability as an area requiring further research and development. Early hypotheses about catalyst deactivation focused attention on the organic overload of the catalyst sites and resulting carbon fouling of the catalyst or slow oxidation of the nickel metal catalyst under steaming conditions.

Concerns about oxidation of the catalyst or carbon laydown on the catalyst have been alleviated during the current CRS tests by results of analys is of used catalysts. We now conclude that carbon fouling is a symptom of loss of catalyst activity, not the cause. Carbon deposition on the catalyst has barely been measurable at less than $1 \%$ following successful experiments. 0xidation of the catalyst has not been encountered in any of the used catalysts. The crystalline forms in the catalyst were determined by $x$-ray diffraction (XRD). Nickel metal was the primary crystalline form of nickel in all cases.

When the catalysts were degraded, loss of activity for both gasification and methanation was evident. Loss in gasification activity usually included 
less COD reduction and higher levels of larger hydrocarbon gas species $\left(C_{2}\right.$ to $\left.\mathrm{C}_{4}\right)$. Less methanation resulted in lower concentrations of methane and higher concentrations of hydrogen and carbon dioxide. Carbon monoxide was produced at immeasurably low levels $(<0.05 \%)$ generally and less than $0.5 \%$ in cases of no or minimal catalytic effect. We are still investigating the causes of catalyst deactivation and means of maintaining catalyst activity in our system. Tests with model compounds have allowed us to operate without concern for traditional nickel metal catalyst poisons such as sulfur or chlorine. These compounds may have played a role in the results obtained from cheese whey and spent grain.

\section{PROCESS KINETICS}

The results of the CRS tests demonstrate that different feedstocks react at different rates in the catalytic gasification system. Breakdown of complex chemical feedstocks by pyrolysis and steam-reforming must play a major role in the overall kinetics of the process.

\section{Physical Characterization of the System}

The residence time in the reactor can only be approximated. At the temperatures of the experiments (around $360^{\circ} \mathrm{C}$ ), the densities of the liquid and vapor phases of water change quickly as a function of temperature. In addition, the vapor pressure of water increases dramatically as the temperature increases and approaches the critical point. In the tubular reactor, the amount of water in the vapor phase was a function of the temperature of the reactor since it was a direct function of the pressure differential between the vapor pressure of water at that temperature and pressure of the gas product/water vapor mixture leaving the reactor, i.e., the total operating pressure of the reactor. Also, the amount of water vapor depended on the amount of product gases generated from the organic feed. As the product gases formed, they acted as diluents to reduce the partial pressure of the water in the vapor phase, which caused more water to pass into the vapor phase to maintain the water partial pressure equal to the vapor pressure of water at the reactor temperature. The total residence time of all phases in the reactor was reduced as more water was vaporized either in proportion to more gas 
production or if the temperature was increased, causing an increase in the vapor pressure of water. However, the reactor was not isothermal nor was the gasification instantaneous. Therefore, the effects of temperature and gas production varied along the length of the reactor.

Since this CRS was intended for process development purposes, usable design information was also expected from the experiments. Although residence time in the catalyst bed is important in understanding the chemical mechanisms in order to optimize operation of the system, liquid hourly space velocity (LHSV) in terms of $L$ feedstock (at ambient conditions)/L catalyst/hr can provide information for scaling up the operation of the tubular reactor. In this case, we used the portion of the catalyst bed at temperature as the catalyst volume. Since the feedstock entered the tubular reactor at ambient temperature, the bottom portion of the reactor was used to preheat the feedstock to operating temperature. The portion of the catalyst bed that served as the preheat zone varied with the feed rate. In the preheat zone the metal catalyst acted primarily as a heat transfer surface. Although it has potential to facilitate the decomposition of the feedstock by catalysis of hydrogenation reactions, little hydrogen is available at the lower temperatures.

The residence time in the reactor varied with the feed rate. It was also highly sensitive to the operating temperature and pressure. In addition, it was a function of the apparent pore volume of the catalyst. Furthermore, the residence times of the gas and liquid phases will be different. These complications underscore the utility of using the LHSV instead of reactor residence times. Table 8 provides some LHSVs and calculated residence times for comparison.

The residence time can be further quantified by using flow data for pseudotracer experiments. Chemical tracer experiments can be used to determine residence time in a reactor wherein continuous monitoring of the product stream can determine the time required for the controlled release of a chemical to pass through the reactor. In the CRS tests, cessation of product gas flow after replacement of the organic-containing wastewater with pure water was monitored. The time delay between changeover in feedstock and the point when the gas flow began to drop was hypothesized to be the liquid phase 
TABLE 8. Calculated Liquid Hourly Space Velocities (LHSVs) and Residence Times

\begin{tabular}{|c|c|c|c|c|c|c|c|c|}
\hline $\begin{array}{l}\text { Feed } \\
\text { Rate }\end{array}$ & $\begin{array}{l}\text { Bed Ten } \\
\text { Bottom }\end{array}$ & $\begin{array}{l}\text { perature } \\
\text { Middle }\end{array}$ & $\frac{{ }^{\circ} \mathrm{C}}{\text { Top }}$ & $\begin{array}{l}\text { Catalyst } \\
\text { Vol, L (a) }\end{array}$ & $\begin{array}{c}\text { LHSV, } \\
\text { L Feed/ } \\
\text { L Catalyst/ } \\
\text { hr }\end{array}$ & $\begin{array}{l}\text { Catalyst } \\
\text { APV, L (b) }\end{array}$ & $\min _{\min }(c)$ & $\begin{array}{l}\text { Space } \\
\text { Time, } \\
\text { hr } \\
\end{array}$ \\
\hline 0.5 & 340 & 365 & 365 & 0.66 & 0.8 & 0.53 & 31 & 1.25 \\
\hline 1.0 & 310 & 360 & 360 & 0.63 & 1.6 & 0.50 & 15 & 0.62 \\
\hline 1.5 & 250 & 360 & 360 & 0.60 & 2.5 & 0.48 & 9.4 & 0.40 \\
\hline 2.0 & 200 & 350 & 350 & 0.55 & 3.6 & 0.44 & 7.0 & 0.28 \\
\hline 2.3 & 180 & 350 & 350 & 0.50 & 4.6 & 0.40 & 5.6 & 0.22 \\
\hline
\end{tabular}

(a) Catalyst at temperature [total catalyst volume $=927 \mathrm{ml}$ (72 in. reactor) minus 6 in. bottom bed support minus 1.5 in. top void $=0.83 \mathrm{~L}]$.

(b) Assuming Ni-0750 catalyst with $80 \%$ APV (see Table l).

(c) In catalyst APV at 3000 psig; liquid phase only assumed.

residence time. Gas product flow did not completely stop as residual organics in the catalyst pores continued to react. The delay was a function of feed rate as shown in Figure 2. The data in Figure 2 represent a liquid phase residence time that is somewhat longer than that calculated for Table 8 because the data represent time in the total reactor system, from feed inlet to gas sample point, as opposed to time in the catalyst bed at temperature. Kinetics Calculations

As shown in our earlier reports, the Carberry reactor configuration used in the CRS could generate useful kinetic information for the process. First order kinetics were suggested for para-cresol and hexone COD conversion at reactor concentrations less than $1000 \mathrm{ppm}$ COD. Above that level, the reaction rate fell off, suggesting a tendency toward zero order reaction because of saturation of the catalyst sites [8aker et al. 1988]. Other experimental results with sorghum at high $C O D$ levels suggested zero order reaction [E1liott et a1. 1989], as did some privately funded experiments with spent grain.

As seen in Table 9, the tubular reactor results can be compared with the projections from the earlier Carberry reactor experiments. The reaction rate constant, $\mathrm{K}$, from the Carberry experiments for hexone was $16 \mathrm{hr}^{-1}$ at $350^{\circ} \mathrm{C}$ in the range from 1 to $10 \mathrm{~g} / \mathrm{L} \mathrm{COD}$. In the tubular reactor tests the reaction was 


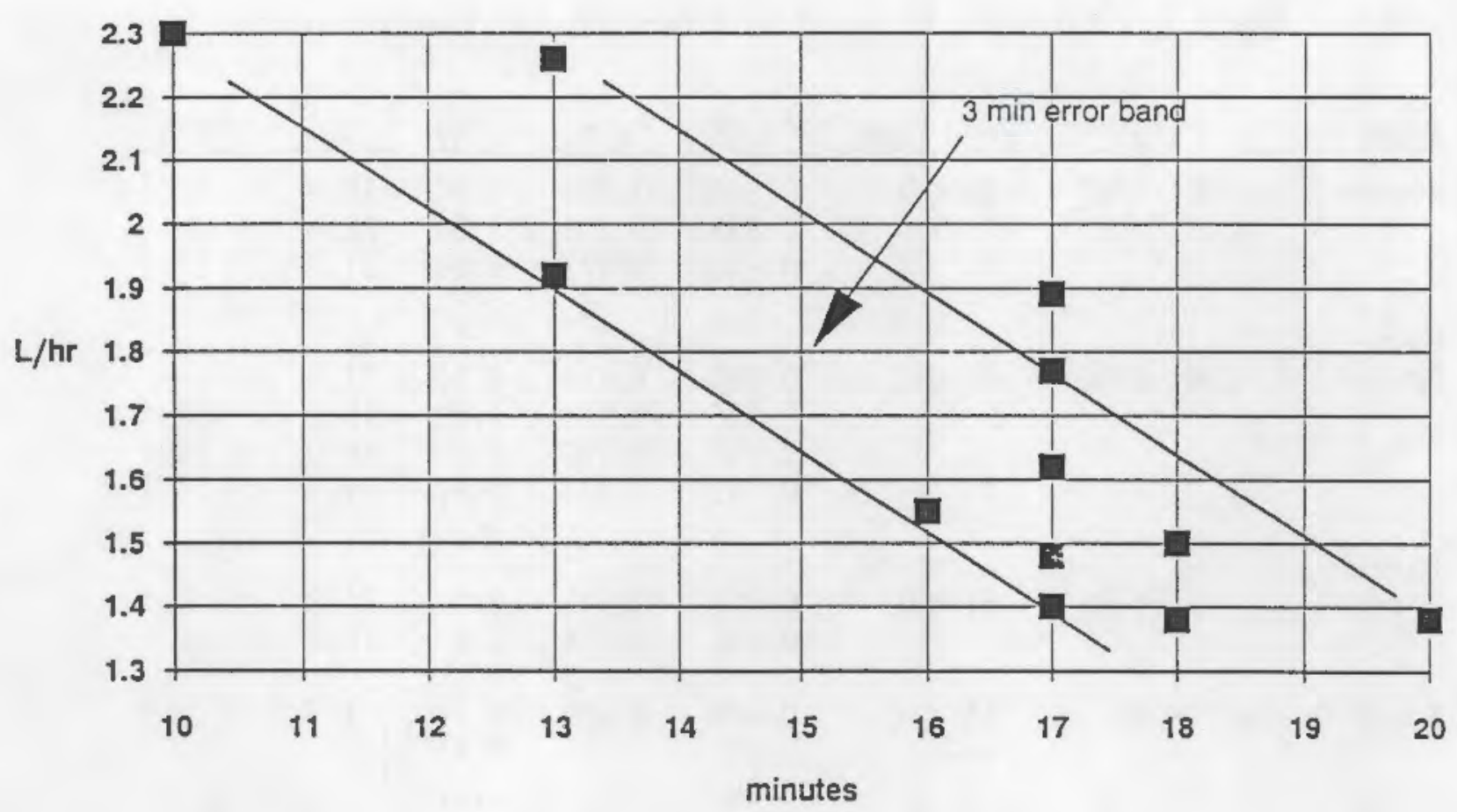

FIGURE 2. Pseudotracer Test Results

essentially complete in all cases even though the initial concentration of the feedstock was much higher $(39 \mathrm{~g} / \mathrm{L}$ COD). As a result, the $\mathrm{Ks}$ calculated in Table 9 indicate an increasing average rate constant in the tubular reactor with increasing flow rate.

In the case of para-cresol, the rate constant appears to peak at about $21 \mathrm{hr}^{-1}$ at a concentration of $48 \mathrm{~g} / \mathrm{L}$ COD compared with $28 \mathrm{hr}^{-1}$ at concentrations below $\mathrm{I} \mathrm{g} / \mathrm{L}$ COD in the Carberry reactor. Further increase in the feed rate apparently does not cause a higher rate of reaction, suggesting the existence of other rate limitations at higher feed rates or concentrations. other results with phenol at twice the concentration show that a similar $\mathrm{K}$ can be achieved $\left(26 \mathrm{hr}^{-1}\right)$ without appearing to reach the maximum feed rate.

In these cases the comparison with Carberry results must be qualified by the fact that different catalysts were used in each series of tests. Comparison of the two catalysts (G-65RS and $\mathrm{Ni-0750)}$ in the tubular reactor with para-cresol suggests that the catalyst used in the Carberry experiments (G-65RS) has only a slightly lower $K$ at comparable conditions. Similar 
TABLE 9. Kinetics Calculations for Tubular Reactor Tests

\begin{tabular}{|c|c|c|c|c|c|c|c|}
\hline Feedstock & Catalyst & Feed Conc. & $\mathrm{x}_{\mathrm{aCOD}}$ & $x_{\mathrm{aGAS}}$ & LHSV $K$ & $\mathrm{~K}_{\mathrm{COD}}{ }^{(\mathrm{a})}$ & $\mathrm{K}_{\mathrm{GAS}}{ }^{(\mathrm{a}}$ \\
\hline $\begin{array}{c}\text { Hexone } \\
" \\
n\end{array}$ & $\begin{array}{c}\mathrm{Ni}-0750 \\
" \\
"\end{array}$ & $\begin{array}{l}39 \mathrm{~g} / \mathrm{L} \\
" 1\end{array}$ & $\begin{array}{l}0.9988 \\
0.9988 \\
0.9990\end{array}$ & $\begin{array}{l}0.998 \\
1.002 \\
0.977\end{array}$ & $\begin{array}{l}2.50 \\
3.38 \\
4.60\end{array}$ & $\begin{array}{l}16.8 \\
22.4 \\
31.4\end{array}$ & $\begin{array}{l}15.5 \\
17.1\end{array}$ \\
\hline $\begin{array}{l}\text { Para- } \\
\text { Cresol } \\
\text { " } \\
" \\
"\end{array}$ & $\begin{array}{l}\mathrm{Ni}-0750 \\
" \\
" \\
"\end{array}$ & $\begin{array}{l}48 \mathrm{~g} / \mathrm{L} \\
" 1 " \\
"\end{array}$ & $\begin{array}{l}0.995 \\
0.996 \\
0.997 \\
0.991\end{array}$ & $\begin{array}{l}1.014 \\
0.993 \\
0.990 \\
0.915\end{array}$ & $\begin{array}{l}2.13 \\
2.50 \\
3.43 \\
4.60\end{array}$ & $\begin{array}{l}11.3 \\
13.8 \\
20.0 \\
21.4\end{array}$ & $\begin{array}{l}-1 .- \\
12.4 \\
15.9 \\
11.2\end{array}$ \\
\hline $\begin{array}{l}\text { Para- } \\
\text { Cresol } \\
\text { " }\end{array}$ & G-65BRS & ${ }_{11}^{51} \mathrm{~g} / \mathrm{L}$ & $\begin{array}{l}0.991 \\
0.991\end{array}$ & $\begin{array}{l}0.943 \\
0.914\end{array}$ & $\begin{array}{l}3.0 \\
3.6\end{array}$ & $\begin{array}{l}14.3 \\
16.8\end{array}$ & $\begin{array}{l}8.7 \\
8.8\end{array}$ \\
\hline$\underset{\text { Spent Grain }}{"}$ & \begin{tabular}{l} 
PK-5 \\
\hdashline-- \\
--
\end{tabular} & $\begin{array}{l}36 \mathrm{~g} / \mathrm{L} \\
\ldots \\
\ldots\end{array}$ & $\begin{array}{l}0.699 \\
0.99 \\
0.90\end{array}$ & 0.583 & $\begin{array}{l}2.41 \text { (b) } \\
0.63(\mathrm{~b}) \\
1.27\end{array}$ & $\left\{\begin{array}{l}1.7 \\
0\end{array}\right.$ & 2.1 \\
\hline Phenol & $\underset{n}{\mathrm{PK}-5}$ & $43 \mathrm{~g} / \mathrm{L}$ & $\begin{array}{l}0.9985 \\
0.999\end{array}$ & $\begin{array}{l}0.990 \\
1.060\end{array}$ & $\begin{array}{l}1.7 \\
2.5\end{array}$ & $\begin{array}{l}11.0 \\
17.3\end{array}$ & $\begin{array}{l}7.8 \\
---\end{array}$ \\
\hline $\begin{array}{c}\text { Phenol } \\
\text { " } \\
\text { " }\end{array}$ & $\begin{array}{l}\mathrm{Ni}-0750 \\
" \\
" \\
"\end{array}$ & $\begin{array}{l}108 \mathrm{~g} / \mathrm{L} \\
" \\
"\end{array}$ & $\begin{array}{l}0.9997 \\
0.9995 \\
0.9995 \\
0.994\end{array}$ & $\begin{array}{l}0.992 \\
0.989 \\
0.995 \\
0.920\end{array}$ & $\begin{array}{l}1.74 \\
2.58 \\
2.80 \\
3.62\end{array}$ & $\begin{array}{l}14.2 \\
19.5 \\
21.1 \\
26.5\end{array}$ & $\begin{array}{r}8.5 \\
11.6 \\
14.7 \\
9.0\end{array}$ \\
\hline
\end{tabular}

(a) $K=-\ln \left(1-X_{a}\right) / t$ where $t$ is space time (1/LHSV). (b) Calculated assuming given conversion and $\mathrm{K}$.

comparisons of the PK- 5 catalyst with the Ni-0750 catalyst using phenol feedstock suggest that the PK-5 is lower in activity because similar K values resulted from the test with only half the concentration of feedstock as used in the $\mathrm{Ni}-0750$ test.

The spent grain data can be qualitatively compared with the sorghum data [E11iott et a1. 1989] and spent grain data [Baker et al. 1989] from the Carberry reactor. In the earlier Carberry tests (using G-65RS), an essentially zero order kinetic rate was measured in the concentration range of 4 to $14 \mathrm{~g} / \mathrm{L} \mathrm{COD} \mathrm{at} 400^{\circ} \mathrm{C}$ for sorghum with a single spent grain data point falling in the same range. Tubular tests with the PK-5 catalyst showed a saturation 
of the catalyst system and resulted in a $10 \mathrm{~W} \mathrm{~K}$ of $3 \mathrm{hr}^{-1}$ at $36 \mathrm{~g} / \mathrm{L} \mathrm{COO}$ at $360^{\circ} \mathrm{C}$ compared with about $12 \mathrm{hr}^{-1}$ at $<10 \mathrm{~g} / \mathrm{L}$ at $350^{\circ} \mathrm{C}$ for spent grain in other proprietary tests.

These $\mathrm{K}$ values are deceptively low. Limitations other than the catalytic reaction rate are probabiy overriding. Although it is evident that extended residence time in the reactor is necessary to achieve high conversion of the spent grain, it is difficult from the limited data to determine with any precision how much additionat time is needed.

A worst case estimate would be to assume first order reaction kinetics for the spent grain data point, which results in a calculated space time of $95 \min \left(0.63 \mathrm{LHSV}\right.$ ) for $99 \% \mathrm{COD}$ conversion of the spent grain at $360^{\circ} \mathrm{C}$. However, the other extreme would be to assume zero order kinetics, and then the required space time would be $35 \mathrm{~min}$ ( 1.71 LHSV). Another way of considering these results is that the current catalyst bed $(0.605 \mathrm{~L})$ would need to be expanded to between $0.85 \mathrm{~L}$ and $2.3 \mathrm{~L}$ in order to attain sufficient residence time for $99 \%$ conversion with the PK-5 catalyst while maintaining the current minimum velocity for tar carry through in the bed. Clearly, more experimentation is needed to better define the reaction rate for design purposes. In addition, since the PK-5 catalyst was shown to be iess active with paracresol as the feedstock, significant improvements in processing rates with other catalysts are possible with spent grain as the feedstock. 


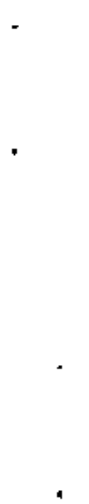




\section{CORROSION ABATEMENT REVIEW}

A portion of the effort in this project was used to review the corrosion concerns related to the process. There is limited experience on corrosion abatement at TEES processing conditions; 1jkewise literature information is not directly applicable in most cases. The corrosion problem will be feedstock specific to some degree. Specific potential corrosion probiems have been identified:

- chemical corrosion - caused by either transient organic acids or carbon dioxide dissolved in the water

- hydrogen embrittlement - caused by high partial pressure of hydrogen

- stress corrosion cracking - caused by either chloride or alkali.

Chemical corrosion from organic acids and dissolved carbon dioxide wi]l impact all applications. The stress corrosion cracking from alkali or chloride may be avoided with clean feedstocks. Hydrogen embrittlement can be avoided if high conversion/low temperature operations are maintained. Selecting materials of construction must take into account the operating conditions of the particular equipment component and the composition of the process stream at that point in the process.

\section{CHEMICAL CORROSION}

In general, high temperatures accelerate corrosion processes. A 10-fold change in corrosion rate is not uncommon for a temperature change of $30^{\circ} \mathrm{C}$ under aqueous corrosion conditions [Elliott 1989]. Unlike most hightemperature reactions, TEES is not an oxidation process. The complex chemistry in TEES involves reactions that both oxidize and reduce different chemical species. No free oxygen is expected to exist in the system. We expect that metal oxide coatings will form on the vessel and piping walls and inhibit corrosion, but oxidative types of corrosion are not expected to be significant. The TEES situation is unlike wet air oxidation, which requires titanium reactors operating at the temperature limit because of the corrosion potential. In supercritical wet oxidation the principal question is the cost 
and durability of the equipment [Breton et al. 1988]. However, titanium cannot be used above $175^{\circ} \mathrm{C}$ if hydrogen is present because of embrittlement from hydride formation [Gutzeit, Merrick, and Scharfstein 1979] and therefore could not be used in TEES. TEES is more similar to coal liquefaction in its operating temperature, pressure, and potential corrodents. However, erosion by coal particles in valves and pumps has been found to be the biggest problem in coal processing. Corrosion in fractionating equipment resulting from chlorides and organic acids and amines has also been noted, although hydrogen resistance may potentially be the biggest corrosion problem for these processing plants [Sorell et a]. 1986].

\section{HYOROGEN EMBRITTLEMENT}

Hydrogen embrittlement is caused by decarburization of steel by reaction with hydrogen. Hydrogen embrittlenent is not expected to be a major problem in TEES but must be considered since significant partial pressures of hydrogen are expected [API 1983]. Given the operating temperature at $350^{\circ} \mathrm{C}$ and hydrogen concentrations below 10 vol\% of the operating pressure of 3000 psig, conditions are not severe enough to require any more special construction material than 0.5 Mo alloy steel. Although 0.5 Mo steel has been used for service with hydrogen at temperatures above $260^{\circ} \mathrm{C}$, recent construction has preferred low alloy steel $(2.25 \mathrm{Cr} / 1 \mathrm{Mo})$ for long-term resistance to failure in hydrogen service [Chiba et a1. 1985]. Carbon steel would be acceptable at these operating conditions if the hydrogen content of the gas could be held below $3.3 \%$ (100 psig partial pressure).

\section{STRESS CORROSION CRACKING}

Unlike many corrosion mechanisms, stress corrosion cracking (SCC) requires a threshold stress, below which no corrosion occurs. It depends on the metallurgical condition of the alloy. A few specific environments cause SCC for a given alloy, but frequently the same environment does not crack other alloys. SCC may occur in environments considered mild, j.e., low uniform corrosion rate. Long periods of time (often years) may pass before cracks become visible, then cracks propagate quickly. SCC is not really 
understood in most cases. Usually it is difficult to define a meaningful minimum level of impurity because corrosion can be localized. Temperature is important, especially heat exchanger wall temperatures [Henthorne 1971].

A specific case of SCC was analyzed in the Biomass Liquefaction Experimental Facility, formerly at Albany, Oregon. In that case operations at 3000 psig and $290^{\circ} \mathrm{C}$ to $400^{\circ} \mathrm{C}$ resulted in pipe cracks in 316 SS after less than $1000 \mathrm{hr}$. The cause was attributed to halogen $(C 1+B r+I=100-200 \mathrm{ppm})$ in the presence of stress, resulting from inadequate allowance for pipe expansion. Alkali was a less likely suspect, although sodium concentration was 500 to $5000 \mathrm{ppm}$. The problem was handled through rebuilding the system with buttwelded components and proper stress relief through revised piping layout and revised welding techniques [Rust 1982].

\section{CHLORIDE CORROSION}

Literature references to chloride cracking do not discuss explicitly the TEES-like environments. Whereas chloride (15.2\%) tends to decrease the rate of corrosion from carbon dioxide ( 5 to 100 psig partial pressure) at low temperature, $65^{\circ} \mathrm{C}$; it tends to increase corrosion at higher temperature, $175^{\circ} \mathrm{C}$, in low alloy steels (5-13Cr/0.5-1.5Mo) [0akwood 1979]. According to the manufacturer, while Incone 600 is good for black liquor equipment (strong alkali and sulfur) and syngas environment, Inconel 625 (containing Mo) is recommended for chloride-containing environments. Black liquor is probably not chloridefree, but it is handled at low pressure, so stress is not a contributing factor. However, all the Inconels and Incoloys are listed by the manufacturer as good to excellent for resisting chloride cracking, while the nonmolybdenum alloys are not recommended for hydrochloric acid use. The nonmolybdenum Inconels are listed as acceptable for seawater use.

In water containing percent levels of chlorides (such as seawater and probably higher than found in TEES), pitting of austenitic 304 SS or 316 SS is a serious problem, even at ambient conditions. Pits are deep and once started progress rapidly through the metal (anodic tip of pit is driven by the large cathodic area of the bulk metal). Pitting may not begin immediately but may incubate for several years. Pitting occurs more readily in stagnant areas and 
tends to progress downward [Kirby 1980]. Stainless steels can be used successfully with seawater if the water is kept moving at sufficient velocity to prevent formation of deposits which lead to pitting [Fontana and Greene 1978]. Temperature accelerates pitting; molybdenum inhibits pitting. Chlorides can cause SCC in order of Na<Ca<Fe<Mg (based on increasing acidity) [Kirby 1980]. 18-8 stainless steel can be used at $300^{\circ} \mathrm{C}$ for only a limited time in chloridecontaining solutions: $20 \mathrm{hr}$ at $100 \mathrm{ppm}$ or $200 \mathrm{hr}$ at $10 \mathrm{ppm}$. Use at $350^{\circ} \mathrm{C}$ could reduce time to failure by 1 to 2 orders of magnitude [Lancaster 1976]. Cracking can be expected in the susceptible austenitic alloys at temperatures as low as $120^{\circ} \mathrm{C}$ and can occur in only $2 \mathrm{hr}$ at $200^{\circ} \mathrm{C}$, at $875 \mathrm{ppm}$ of $\mathrm{NaCl}$. Dissolved oxygen or other oxidizing species is critical to the cracking of austenitic stainless steels in chloride solutions, and if the oxygen is renoved, cracking witl not occur.

Although carbon steel is less resistant to general corrosion, it is more resistant to SCC than the stainless steels. Thus, under SCC conditions, such as heat exchangers used in contact with seawater or brackish water, carbon steel is often found to be more satisfactory than stainiess steel [Fontana and Greene 1978].

\section{SUGGESTIONS FOR CORROSION ABATEMENT BASED ON LITERATURE REVIEW}

Although no specific example of material testing applies to the combination of conditions found in the TEES process, the literature seems to point toward Inconel as the appropriate alloy type for the critical processing components as a result of the combination of corrosion-causing mechanisms. Neither Hastelioy nor titanium (nor more exotic metals) should be necessary. Inconel 625, which contains molybdenum while Inconel 600 does not, may be needed for the chlorides. The high-pressure feed/product heat exchanger will require the same alloy as the reactor. Carbon steel should be sufficient on the cold front end and tail end of the process and could be used throughout if the hydrogen partial pressure is maintained at a low level $(<3.3 \%)$.

Two other alloys seem to be interesting possibilities for the hightemperature, high-pressure equipment, ferritic alloys and Alloy 20 . The ferritic stainless steels are more resistant to SCC than the austenitic 
stainiess steels and their high-temperature limitation ( $<540 \mathrm{C})$ is not a problem for TEES. In particular, the high-purity ferritic stainless steels, 29-4 and 26-1, are described as far superior to austenitic steels for chloride resistance, and 29-4 shows good resistance to pitting and crevice corrosion and can be compared to Hastelloy $C$ and titanium. A11oy 20 is described as more corrosion resistant than any nickel chrome stainless steel under all conditions [Fontana and Greene 1978]. Working these alloys requires more controlled procedures, especially welding. These alloys should have some cost advantage over Inconel, but the carbon steel would stitl be least expensive, if it is appropriate to use it.

\section{EXPERIMENTAL RESULTS WITH CORROSION-TESTING COUPONS}

In a related project at $\mathrm{PNL}$, a selection of stressed coupons, including the main alloys under consideration for the TEES reactor system, were incubated in an organo-chloride-containing water solution batch at process conditions to simulate exposure in the process. After 3 months exposure, the extent of corrosion was minimal on all the coupons. Carbon steel seemed to be nearly as resistant as the austenitic stainless steels and the more exotic Inconel and Hastelloy alloys. No signs of pitting or cracking were evident on any coupon. All the coupons were coated with a black residue that rinsed off in water. 


\section{TEES ENERGY BENEFIT AND ECONOMIC ANALYSIS}

The energy benefit and economic analysis for TEES, conducted by PNL and Onsite*0fsite, included capital and operating cost estimation for the process as it could be applied in four different industrial settings, and evaluation of the energy savings and economical benefit of incorporating the process into existing industrial processes. The analysis is summarized here; complete details will be published in a companion report.

There are several unique features of the TEES process that distinguish it from other thermochemical recovery technologies such as combustion and gasification. Three of the most important aspects of the technology that demonstrate its economic attraction are summarized below:

- The use of a low-temperature $\left(350^{\circ} \mathrm{C}\right.$ to $\left.400^{\circ} \mathrm{C}\right)$, pressurized $(2000$ to 4000 psig) reaction environment facilitates more efficient heat recovery from reaction products, which in turn allows the use of very high-moisture (up to $95 \mathrm{wt} \%$ moisture) feedstocks. Heat transfer is improved under these conditions because of the relatively high fluid density of the product stream, which permits the use of compact, less costly heat recovery equipment. The reaction conditions serve to shift reaction equilibrium towards the production of methane, as opposed to lower valued fuel gases such as carbon monoxide and hydrogen. Thus, the product from the TEES process is more compatible with existing natural gas burners than the lower Btu gas available from conventional high-temperature gasifiers.

- High reaction rates, even at the low temperatures employed in the process $\left(350^{\circ} \mathrm{C}\right)$, are achieved by the use of commercial nickel catalysts. Residence time requirements for many feedstocks are estimated to be 10 to 20 min or less at temperature, which compares favorably with the requirements in conventional thermal systems operating at much higher temperatures (typically above $600^{\circ} \mathrm{C}$ ).

- The TEES concept can be used to produce significant quantities of energy for many energy-intensive industries and at the same time solve byproduct disposal (both solid and liquid) and other environmental problems such as wastewater cleanup. The process can serve as a standalone gasification plant or can be integrated into existing industrial plants to accomplish specific energy, economic, and environmental goals. 
In comparison with anaerobic digestion, which has shown potential as a means for simultaneously reducing the biochemical oxygen demand (BOD) and recovering energy from selected waste streams, the TEES concept offers two major advantages:

- In the TEES process, rate enhancements of at least 2 to 3 orders of magnitude are attained in comparison with anaerobic digestion. This increase in rate results in significant reductions in reactor volume and space requirements for the TEES approach. The higher reaction rates also result in a process that is more responsive to rapid fluctuations in waste load or changes in waste composition.

- The TEES process has the ability to efficiently convert biochemically "inert" waste components such as lignins and lignin byproducts. For many waste streams, this improved conversion will result in higher yields of gas from the waste streams and greater reductions in discharge $B O D$ and $C O D$ levels than can be obtained with bioconversion.

The purpose of this project is to facilitate the development of the TEES technology for converting wet industrial wastes to significant quantities of methane to provide energy conservation and reduced disposal costs. Many specific industrial wastes (food processing, beverage production, pharmaceutical, petroleum refining, and chemical manufacturing) currently cannot be economically incinerated, landfilled, or sewered. These waste streams consist of high-moisture solids, wet sludges, or highly contaminated wastewater that contain significant amounts of organic carbon which, if appropriate technology were available, could be converted to a useful fuel form.

TEES is more than just another gasification system as it can be integrated into an existing plant to solve several energy and environmental needs. TEES is a unique thermocatalytic gasification concept that converts wet industrial and food processing wastes to methane (for use in existing boilers) and carbon dioxide (for bottling, packaging, and other plant uses) while at the same time cogeneration, wastewater treatment, and reduction in solid waste handling can also be achieved. The TEES concept is distinctive in its application to industry, and no biological or thermal processes exist that have the potential to provide the overall systems impact of TEES.

To fully define and analyze the concept and evaluate its integration into specific industrial operations, Onsite*0fsite performed an engineering 
design and economic analysis of the TEES process as it might be incorporated into existing industrial settings. This information is needed before the process can be advanced to commercial application. Onsite*0fsite was selected for the work because they hold the 1icense to TEES and had developed both designs for the process equipment and the industrial contacts necessary for obtaining the needed information. The system analysis thus performed provides DOE and industry with the information required to evaluate the fully integrated concept in various industrial applications.

\section{ECONOMIC ANALYSIS CONCLUSIONS}

The TEES process can be incorporated into existing industrial settings to provide numerous cost savings such as energy return (as fuel gas or methane) to the plant, reduced waste transport and disposal costs, reduced water processing costs, internal production of a useful chemical (carbon dioxide), and conservation of important water resources.

A broad field of application of the TEES process was identified which suggested the large potential impact by the utilization of TEES. Just within the three food processing cases, the potential annual feedstock is 2 million tons cheese whey (actually wasted, total is much larger), 0.4 million tons of grape pomace, and 9.4 million tons of spent grain (much of which is used as animal feed). Net gas production would be $1.2,0.3$, and 8.9 trillion Btu annually from the three feedstocks, respectively. The organic chemical waste stream analyzed in this study was a relatively small operation, and it is expected that the scale of application of TEES to organic chemical wastes is probably much larger than what was identified for food processing wastes.

In all cases there was a net energy production from the waste stream. The amount of net gas production in the four cases varied from 18,481 SCF/day for the organic chemical waste, to 151,116 SCF/day for cheese whey, to 1,939,797 SCF/day for grape pomace, to 2,218,909 SCF/day for the spent grain. In all cases, the net gas production was a medium-Btu fuel gas that could be further upgraded by membrane separation into high-Btu gas ( $90 \%$ methane) and carbon dioxide byproduct. 
The analysis of the applications studied showed that only the organic chenical waste process was attractive in the existing energy/economic environment. However, the spent grain case would be attractive if byproduct credits for sales of the spent grain as animal feed were not considered. The grape pomace and cheese whey cases will become attractive as alternative disposal practices are curtailed. Adequate development time exists to ready TEES for commercialization as energy prices rise and environmental regulations become more stringent.

\section{RECOMMENDATIONS FROM THE ENERGY BENEFIT AND ECONOMIC ANALYSIS}

Since the organic chemical waste processing appears to be economically viable, further effort is recommended in this area of application of the TEES process. The total amount of organic chemical waste is so large that it is likely to be the major application of TEES. Stream-specific processing data are needed for a full analysis of the applicability of TEES to these wastewater streams. More information is required from the organic chemical manufacturers, especially on the specific definition of the wastewater streams. Success in obtaining information has been 1 imited thus far; a stronger effort is needed, including face-to-face meetings with manufacturers.

Another recommendation is to pursue wide application of TEES in the food processing industry. Several specific applications were studied which showed that the process could be useful to food processors in light of future curtailments of 1 and disposal alternatives. The three cases analyzed in this research represented only a fraction of the potential application of the process. A recent privately funded study of food processors stated that over 200 million tons/yr of raw agricultural commodities are harvested annually in the USA, and less than $50 \%$ of these materials end up as usable products, which leaves the balance as potential feedstock for TEES.

For both of these applications the major effort recommended is a combination of data acquisition and technology transfer. More tests need to be performed in the reactor system with specific feedstocks of interest to industry. In return, information on the feedstock composition, availability, and alternative uses must be obtained from industry. By this cooperative 
research, a sense of mutual interest and trust can be developed between PNL and industry to facilitate the technology transfer process.

The final recommendation is the use of tEES for the gasification of high-moisture (herbaceous, marine, and aquatic) biomass feedstocks and for treatment of wastewater streams from both thermochemical and biochemical conversion of biomass as biomass research expands to meet future energy needs. 


\section{RELATED PUBLICATIONS}

Within this project, two presentation manuscripts were prepared and published:

- "Usable Energy from Wet Biomass and Waste" by D. C. Elliott,

A. G. Fassbender, E. G. Baker, R. S. Butner, P. M. Molton,

G. G. Neuenschwander, and L. J. Sea Tock, Jr. BN-SA-3104, presented at the Solid Waste Energy Conference, February 21-23, 1990, in College Station, Texas.

- "Bench-Scale Reactor Tests of Low-Temperature, Catalytic Gasification of Wet Industrial Wastes" by D. C. Elliott, G. G. Neuenschwander, E. G. Baker, R. S. Butner, and L. J. Sealock, Jr. PNL-SA-17707, presented at the 25th Intersociety Energy Conversion Engineering Conference, August 12-17, 1990, in Reno, Nevada. PubTished by AIChE, Volume 5, pp. 102-106, of the Proceedings. American Institute of Chemical Engineers, New York.

A companion report is also being published by PNL which provides the details of the energy benefit and economic analysis of the process. 


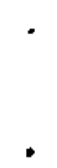




\section{REFERENCES}

API. 1983. Steels for Hydrogen Service at Elevated Temperatures and Pressures in Petroleum Refineries and Petrochemical P1ants. Publ. 941, 3rd ed. American Petroleum Institute, Washington, D.C.

Baker, E. G., and L. J. Sealock, Jr. 1988. Catalytic Destruction of Hazardous Organics in Aqueous Solutions. PNL-6491-2, Pacific Northwest Laboratory, Richland, Washington.

Baker, E. G., R. S. Butner, L. J. Sealock, Jr., D. C. Elliott, and G. G. Neuenschwander. 1989a. Thermocataiyt ic Conversion of Food Processing Wastes, Topical Report FY 1988. PNL-6784, Pacific Northwest Laboratory, Richland, Washington.

Baker, E. G., R. S. Butner, L. J. Sealock, Jr., D. C. Elliott, G. G. Neuenschwander, and N. G. Banns. 1989b. "Catalytic Destruction of Hazardous Organics in Aqueous Wastes: Continuous Reactor System Experiments." Hazardous Waste \& Hazardous Materia7s 6(1):87-94.

Breton, M., P. Frillici, S. Palmer, C. Spears, M. Arienti, M. Kravett, A. Shayer, and N. Suprenant. 1988. Ireatment Technologies for Solvent Containing Wastes, pp. 377-378. Noyes Data Corporation, Park Ridge, New Jersey.

Chiba, R., K. Ohnishi, K. Ishii, and K. Maeda. 1985. "Effect of Heat Treatment on Hydrogen Attack Resistance of 0.5 Mo Steels for Pressure Vesse1s, Heat Exchangers, and Piping." Corrosion 41(7):415-426.

Elliott, D. C., and L. J. Sealock, Jr. 1985. "Low Temperature Gasification of Biomass Under Pressure." In Fundamentals of Thermochemical Biomass Conversion, eds. R. P. Overend, T. A. Milne, and L. K. Mudge, pp. 937-950. Elsevier Applied Science Publishers, Ltd., London.

Elliott, D. C., R. S. Butner, and L. J. Sealock, Jr. 1988. "Low-Temperature Gasification of High-Moisture Biomass." In Research in Thermochemical Biomass Conversion, eds. A. V. Bridgwater and J. L. Kuester, Pp. 696-710. El sevier Applied Science, London.

Elliott, D. C., L. J. Sealock, Jr., R. S. Butner, E. G. Baker, and G. G. Neuenschwander. 1989. Low-Temperature Conversion of High-Moisture Biomass: Continuous Reactor System Results. PNL-7126, Pacific Northwest Laboratory, Richland, Washington.

Elliott, P. 1989. "Practical Guide to High-Temperature Alloys." In Materials Performance, Materials Selection \& Design, April, pp. 57-66.

Fontana, M. G., and N. D. Greene. 1978. Corrosion Engineering, 2nd ed. McGraw-Hill Book Co., New York. 
Gutzeit, J., R. D. Merrick, and L. R. Scharfstein. 1979. "Corrosion in Petroleum Refinery and Petroleum 0perations." In Metals Handbook, 9th ed., Vol. 13, pp. 1262-1287. American Society of Metals, Metals Park, Ohio.

Henthorne, M. 1971. "Fundamentals of Corrosion." Chem. Eng. May 17:127-132.

Kirby, G. N. 1980. "How to Select Materials." Chem. Eng. November 3:103.

Lancaster, J. F. 1975. "What Causes Equipment to Fail?" Hydrocarbon Processing 54(1):74-76.

Oakwood, T. G. 1979. Corrosion of Alloy Steels." In Metals Handbook, 9th ed., Vol. 13, p. 536, Figure 9. American Society of Metals, Metals Park, ohio.

Pearce, R., and W. R. Patterson. 1981. Catalysis and Chemical Processes. John Wiley \& Sons, New York.

Rust International Corporation. 1982. Final Report: An Investigation of Liquefaction of Wood at the Biomass Liquefaction Facility Albany, Oregon. DOE/NBM 1060, National Technical Information Service, Springfield, Virginia.

Sealock, L. J., Jr., D. C. Elliott, R. T. Hallen, R. D. Barrows, and S. L. Weber. 1981. Kinetics and Catalysis of Producing Synthetic Gases from Biomass, Annual Report. GRI-80/0116, PB82-214347, National Technical Information Service, Springfield, Virginia.

Sealock, L. J., Jr., D. C. ElTiott, R. S. Butner, and G. G. Neuenschwander. 1988. Low-Temperature Conversion of High-Moisture Biomass: Topical Report January 1984 - January 1988. PNL-6726, Pacific Northwest Laboratory, Richland, Washington.

Sore11, G., M. J. Humphries, E. Bullock, and M. Van de Voorde. 1986. "Materials Technology Constraints and Needs in Fossil Fuel Conversion and Upgrading Processes." In International Metals Review, Vol. 31, No. 5, pp. 216-242. 


\section{DISTRIBUTION}

No. of

Copies

\section{OFFSITE}

R. Costello

Biofuel Systems Division

U.S. Department of Energy

Forrestal Building

1000 Independence Avenue

Washington, DC 20585

S. L. Natof

Waste Material Management Division

U.S. Department of Energy

Forrestal Building (CE-222)

1000 Independence Avenue

Washington, DC 20585

S. F. Sobczynski

Division of Improved Energy Production

U.S. Department of Energy

Forresta] Building (CE-142)

1000 Independence Avenue

Washington, DC 20585

12 DDE/Office of Scientific and Technical Information

M. J. Antal

Department of Mechanical

Engineering

University of Hawaii

2540 Dole Street

Honolulu, HI 96822

R. E. Bailey

Kraft Food

2211 Sanders Rd.

Northbrook, IL 60062
No. of

Copies

5 N. G. Banns

Onsite*ofsite, Inc.

2500 E. Foothills Blvd.

Suite 201

Pasadena, CA 91107

S. P. Barone

Gas Research Institute

8600 West Bryn Mawr Avenue

Chicago, IL 60631

R. Beale

Vice President, Operations

Lamb-Weston

P. 0. Box C 1900

Tri-Cities, WA 99302

H. W. Ewart

Tree Top, Inc.

Technical Center

111 S. Railroad Ave.

P. 0. Box 248

Selah, WA 98942

I. Feins

Engelhard Corporation

Catalysts and Chemicals

Division

Men lo Park

Edison, NJ 08818

B. Haley

Miller Brewing Company

651 N. 39th Street

Milwaukee, WI 53233

N. Hinman

Solar Energy Research

Institute

1617 Cole Blvd.

Golden, CO 80401 
No. of

Copies

J. Houken

Technology Manager

Catalyst Division

Haldor Topsoe, Inc.

P. 0. Box 58767

Houston, TX 77258-8767

D. Johnson

NALCO Chemical Co.

1 NALCO Center

Naperville, IL 60563-1198

S. Liederman

c/o Horton Internationa]

238 Main Street

Cambridge, MS 02142

W. M. Mckinney

United Catalysts, Inc.

P. 0. Box 32370

Louisville, KY 40302

H. S. Meyer

Gas Research Institute

8600 W. Bryn Mawr Avenue

Chicago, IL 60631

C. R. Nelson

Gas Research Institute

8600 W. Bryn Mawr Avenue

Chicago, IL 60631

R. Overend

Solar Energy Research

Institute

1617 Cole Blvd.

Golden, CO 80401

J. Pereira

Process Development and Optimization Center

Corporate Research and Development

Anheuser-Busch Companies, Inc.

Executive Offices

One Busch Place

St. Louis, MO 63118
No. of

Copies
R. Radford
Ocean Spray Cranberries, Inc.
Box 195
Markham Star Route
Aberdeen, WA 98520
R. J. Weisskirchen
The Blitz-Weinhard Brewing Co.
1133 West Burnside Street
Portland, OR 97209

\section{FOREIGN}

A. V. Bridgwater

Aston University

Aston Triangle

Birmingham B4 7ET

UNITED KINGDOM

E. Hogan

Bioenergy Division

Energy, Mines and Resources

580 Booth Street

0ttawa, Ontario KIA OE4

CANADA

I. Hunter

Forest Research Institute

Private Bag 3020

Rotorua

NEW ZEALAND

C. Roy

Université Laval

Chemical Engineering Dept.

Faculté des sciences et génie

Pavillion Pouliot

Sainte-Foy, Québec GlK 7P4 CANADA 
No. of

Copies

D. Sanfilippo Research Division

Snamprogett $i$

20097 S. Donato Milanese

Milan, ITALY

K. Sipila

Technical Research Centre of Finland

Laboratory of Fuel and

Process Technology

P. 0. Box 205

SF-02151 Espoo

FINLAND

\section{ONSITE}

DOE Richland Operations office
No. of

Copies

33 Pacific Northwest Laboratory

E. G. Baker

R. S. Butner

D. C. Elliott (20)

E. A. Eschbach

S. R. Gano

G. G. Neuenschwander

L. J. Sealock, Jr.

L. D. Williams

Publishing Coordination

Technical Report Files (5)

R. B. Goranson 
